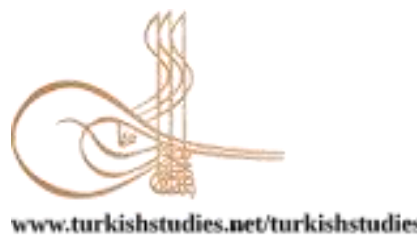

Turkish Studies

www.turkishstudies.net/turkishstudies

eISSN: $1308-2140$

BALAKAN

Sponsered by IBU

Research Article / Araștırma Makalesi

\title{
Binalardan Enerji Üretilmesi ve Akıllı Enerji Yönetimi için Bütünleşik Sistem Mimarisinin Araştırılması, Geliştirilmesi ve Doğrulanması
}

\author{
Research, Development and Verification of an Integrated System Architecture for Energy \\ Generation from Buildings and Smart Energy Management
}

\author{
Hasan Ufuk Gökçe* - Kamil Umut Gökçe**
}

\begin{abstract}
In this work, the "Integrated System Architecture for Energy Generation from Buildings and Smart Energy Management" research project results are presented. This R\&D project is funded by the Scientific Research Council of Turkey (TÜBITAK) within the frame of "Teydeb 1507-Small Medium Enterprises - R\&D Initiation Support Program". In the scope of this research project, integration of renewable off-the-grid building energy generation systems, wireless network embedded devices, multi criteria analysis expert systems, context sensitive monitoring tools and decision support systems are researched, developed and validated. As an outcome of R\&D accomplishments, the "Integrated Building Energy Generation System (IBEGES)" is indigenously developed as an innovative data collection, analysis and optimisation system comprising open and expandable information exchange platform. This indigineous system enables energy performance monitoring and optimization using data warehouse, data mining, intelligent control and web service technologies in order to accomplish an energy plus building concept. The developed technology is tested in a residential building and in the laboratory of the EOS Istanbul Sustainable Energy Solutions A.Ş. to quantify energy production levels. System increases the total energy production levels by optimizing renewable energy generation systems with the support of indigeniously developed wireless network embedded hardware and intelligent software consisting of scenario-based algorithms that can be applied in buildings with various purposes. It has been recorded that the developed system provides energy generation levels between the lowest $10.10 \mathrm{kWh}$ and the highest $24.34 \mathrm{kWh}$ range under diverse seasonal conditions based on optimized off-thegrid energy generation.
\end{abstract}

Structured Abstract: As a net energy importer, Turkey imports 96\% of its oil (EUROSTAT b, 2020) and $76 \%$ of its total energy (Gökçe \& Erol 2020: 108). Turkey paid 350 Billion U.S. Dollars for energy imports between the years 2011 and 2017 (BOTAS, 2017: 17). It is estimated that Turkey will import approx. 1.1 to 1.4 Trillion U.S. Dollars worth of energy until the year 2030 (OME, 2014: 18). Current residential and office buildings significantly contribute to total energy consumption and $\mathrm{CO}_{2}$ emissions. Energy consumption for

*Dr. Öğr. Üyesi, Ar\&Ge Müdürü, EOS İstanbul Sürdürülebilir Enerji Çöz. A.Ş., İTÜ ARI Teknokent, İstanbul. Asst. Prof. Dr., R\&D Director, EOS Istanbul Sustainable Energy Sol. Inc., ITU ARI Teknokent, Istanbul. ufuk.gokce@eos-ses.de ORCID 0000-0001-8010-0703

**Dr. Öğretim Üyesi, Genel Müdür, EOS İstanbul Sürdürülebilir Enerji Çöz. A.Ş., İTÜ ARI Teknokent, İstanbul. Asst. Prof. Dr.-Ing., Managing Director, EOS Istanbul Sustainable Energy Sol. Inc., ITU ARI Teknokent, Istanbul. umut.gokce@eos-ses.de ORCID 0000-0003-2635-7991

Cite as/ Atıf: Gökçe, H. U. \& Gökçe, K. U. (2021). Binalardan enerji üretilmesi ve akıllı enerji yönetimi için bütünleşik sistem mimarisinin araştırılması, geliştirilmesi ve doğrulanması. Turkish Studies, 16(4), 1235-1260. https://dx.doi.org/10.7827/TurkishStudies.48132

Received/Geliş: 02 December/Aralık 2020

Accepted/Kabul: 25 August/Ağustos 2021

Checked by plagiarism software

Published/Yayın: 30 August/Ağustos 2021

CC BY-NC 4.0 
building-related services accounts for approximately 40\% of total EU energy consumption (Itard vd., 2008:19). Buildings are responsible for $36 \%$ of the total $\mathrm{CO}_{2}$ emissions (EC, 2014:18). Reports by the Intergovernmental Panel on Climate Change (IPCC) and the U.S. Department of Energy note that buildings account for 25-30\% of the total energy-related $\mathrm{CO}_{2}$ emissions worldwide (Price, 2006:14).

It is evident that, with the innovative research and development initiatives in the building sector pursuing renewable energy technologies, substantial energy savings and $\mathrm{CO}_{2}$ emission cutbacks can be realised, thus helping to accomplish objectives on climate change and security of energy supply.

According to continuing research in the area of renewable energy generation and legislative drivers initiated by the national and international organizations, the function of integration concepts, energy performance monitoring, analysis methodologies and advanced intelligent control strategies through the unified integration of people, ICT devices and computational resources gain substantial significance for the optimisation of energy generation from buildings.

In this context, the objective of this work is to research a methodology for developing a system which increases the efficiency of renewable off-the-grid energy generation systems in buildings. Ultimately, to monitor and optimise energy generation for reaching an energy plus building solution.

In order to accomplish this objective, new methods and tools are researched which increase system functionality covering the recent building energy regulations, off-the-grid energy systems, wireless network embedded technologies, intelligent control algorithms, monitoring tools and integration of these to the information management backend system-the Data Warehouse (DW) core through an indigenously developed wireless sensor network.

Within the scope of this project, the "EOS Integrated Energy Generation System (EOS-IBEGES)" is developed as a new integrated data collection, analysis and optimisation system using wireless network embedded hardware, multi-dimensional data warehouse core with data mining technologies and scenario based intelligent control algorithms. The developed system consists of the following key elements: (1) Indigenously developed wireless network embedded sensors. (2) Wireless communication protocol. (3) A unique, multidimensional information management platform offering e-services for energy generation relevant performance monitoring and intelligent control using data warehouse technologies, data mining, and web-services. (4) A new, open, extensible data exchange method named the Extraction, Transformation and Loading (ETL) Tool which facilitates the interoperability of the tools. (5) An Intelligent Control module to optimize the energy production of the off-the-grid energy generation systems for the different use cases and scenarios. (6) Context sensitive, web-based, Graphical User Interfaces for multiple stakeholders.

The research is conducted within the "Integrated System Architecture for Energy Generation from Buildings and Smart Energy Management" research project which is funded by The Scientific and Research Council of Turkey (TÜBİTAK) in the frame of "Teydeb 1507 Industry R\&D Start-up Support Programme".

In this work, six development phases are contemplated. In the first phase of the study, the analyses of off-the-grid energy systems, sensors, control units (actuators), and the network structures are analysed to complete the requirements analysis. In the following phase, a specification study was conducted for all components and equipment determined on the basis of requirement analysis, and all associated features were listed. In the third and fourth phases of the project, indeginous hardware design and embedded software development activities are completed based on specification analysis. In the fifth phase, the final software and hardware are integrated for testing and validation purposes. In addition, at this stage, scenario-based intelligent control algorithms are completed to provide energy generation optimization. In the sixth phase system tests were carried out with the deployment of the system in two different test sites. Prototype applications created according to test results were used for patent utility model and commercialization activities.

The developed system is deployed, tested, and energy generation performance are evaluated between 2017 and 2019. In order to test and validate the developed system, two different test sites are established. The first test bed is deployed in the laboratory area of the EOS Istanbul Sustainable Energy Solutions A.Ş. firm which is located at the Istanbul Technical University (ITU) Ar1 Teknokent. This test bed is mainly used for early stage development and continuous improvement activities for system modules. The second test is a residential building in Istanbul. This test bed is used to authenticate the system performance under real occupancy and environmental conditions. Full-size photovoltaic panels, wind turbine, battery pack and grid 
connetion set-up is installed to this building in order to test the final versions of the developed system. It has been logged that the system can provide energy generation levels - the lowest $10.01 \mathrm{kWh}$ and the highest 24.34 $\mathrm{kWh}$ range under different seasonal conditions based on optimized energy generation.

Keywords: Information systems, energy efficiency, information management, decision support systems, system development, renewable energy technologies, smart buildings

Öz: Bu çalışmada, TÜBİTAK Teydeb 1507 KOBİ Ar-Ge Başlangıç Destek Programı çerçevesinde yürütülmüş olan 7130241 proje numaralı "Binalardan Enerji Üretilmesi ve Akıllı Enerji Yönetimi için Bütünleşik Sistem Mimarisinin Geliştirilmesi" projesi ve proje çıktıları sunulmuştur. Bu proje kapsamında binalardan enerji üretilmesine ve akıllı enerji yönetimine yönelik, entegre yapılar, bütünleşik izleme ve analiz metotları, sürdürülebilir yönetim ve karar destek sistemlerini içeren temel araştırma faaliyetleri içerisinde bulunulmuş, şebekeden bağımsız (off-the-grid) yenilenebilir bina enerji üretim sistemlerinin entegrasyonu ile elde edilen Bütünleşik Enerji Üretim Sistemi ele alınmıştır. Bu çalışmaya konu olan "EOS Bütünleşik Bina Enerji Üretim Sistemi" açık ve genişletilebilir bilgi alışverişine olanak sağlayan, yenilikçi bir veri toplama ve enerji üretim ve yönetim sistemi olarak ortaya konmuş, veri ambarı, veri madenciliği, akıllı kontrol ve kablosuz iletişim teknolojilerini kullanarak, enerji performans izleme ve optimizasyonunun gerçekleştirilmesini sağlanmıştır. Bu kapsamda şebekeden Bağımsız Bina Enerji Üretim ve Saklama Sistemleri, Kablosuz Algılayıcı Katmanı, Bilgi İşlem Modülü, İzleme aracı, Akıllı Kontrol ve Optimizasyon Aracı gibi farklı ve birbirleri ile entegre çalışan teknolojiler ele alınmış̧ır. Geliştirilen sistem EOS İstanbul Sürdürülebilir Enerji Çözümleri A.Ş. firmasına ait laboratuvar alanı ve konut binasında uygulanarak enerji üretim performansları ölçülerek test edilmiştir. Geliştirilen sistem 5 farklı kablosuz donanım ve senaryo tabanlı algoritmalardan oluşan yazılım yardımı ile binalardan enerji üretimini destekleyen sistemleri optimize ederek binaların toplam enerji kullanım maliyetini etkin bir şekilde düşürmektedir. Geliştirilen bütünleşik bina enerji üretim sistemi eski veya yeni farketmeksizin farklı kullanım amaçlarına sahip binalarda uygulanabilmektedir. Proje kapsamında 2017-2019 yılları arasında yürütülen testler sonucunda geliştirilen sistemin farklı mevsimsel koşullar altında en düşük 10,1 kWh ile en yüksek 24,36 kWh aralığında enerji üretimi sağladığı kayıt altına alınmıştır.

Anahtar Kelimeler: Bilgi yönetimi, enerji verimliliği, veri yönetimi, karar destek sistemleri, sistem geliştirme, yenilenebilir enerji sistemleri, akıllı binalar

\section{Giriş}

Tüketilen toplam enerjinin üçte ikisini ithal eden Türkiye, sadece petrolde ise tüketiminin \%96'sını yabancı kaynaklardan ithal etmektedir (EUROSTAT b, 2020). Türkiye enerjide ithalata bağımlılıkta 39 Avrupa ülkesi arasında beşinci sırada yer almaktadır (EUROSTAT a, 2020). 19902015 yılları arasında yaklaşık 1,2 trilyon Amerikan Doları tutarında enerji ithalatı gerçekleştiren Türkiye (IEA, 2020), 2017 yılında 37 milyar 204 milyon 849 bin doları bulan enerji ithalat1, 2018 yllında yaklaşık yüzde 15,6 artarak 42 milyar 999 milyon 451 bin dolara yükselmiştir. Ulusal Enerji Denge Tablosuna göre 2017 yılında 145,3 mtpe olan Ülkemizin birincil enerji talebinin 2023 y1l itibarıyla 218 mtpe'ye ulaşması beklenmektedir (BOTAS, 2019: 15).

Türkiye'nin nüfusu 1980-2019 yılları arasında 43 milyondan 82 milyona yükselerek yaklaşık 2 katına ulaşmıştır (Dünya Bankası, 2020a). GSYİH'si 68 milyar dolardan 771 milyar dolara yükselirken 12 katına (Dünya Bankası, 2020b), enerji tüketimi 27 bin TEP'ten 111 bin TEP'e yükselerek 4 katına (EİGM, 2020), kişi başına düşen yıllık $\mathrm{CO}_{2}$ emisyonu salınımı 1723 ton seviyesinden 4448 ton seviyesine yükselerek yaklaşık 3 kat artmıştır (Dünya Bankası, 2020c).

Türkiye'nin 2030 yılına kadar yaklaşık 1,4 trilyon Amerikan Dolar'1 tutarında enerji kaynağı ithal etmesi öngörülmektedir (OME, 2014: 18).

Avrupa Birliği ülkeleri şu anda kullanmış oldukları petrolün \%82'sini ve doğal gazın \% 57'sini ithal etmektedir (EUROSTAT, 2020a). Avrupa Birliği ülkelerinin dış enerji piyasaları ve 
enerji arzı üzerinde çok az etkisi olabilir, ancak iç enerji talebini kontrol edebilir. Enerjide görece yüksek dış bağımlılık için olası bir çözüm, binalardan enerji üretilmesini sağlayarak, enerji verimliliğini arttırmak ve enerji tüketimini azaltmaktır.

Günümüzde Avrupa Birliği ülkelerinde kullanılan toplam enerjinin \%40'1 sadece binalar (konut ve ofis) tarafindan tüketilmektedir (Itard vd., 2008: 19). Avrupa genelinde binalar toplam karbon emisyonlarının \%36'sını üretmektedir (EC, 2011: 48).

Yapılan orta ve uzun vadeli projeksiyonlarda öngörüldüğü̈ üzere, 2030 y1lı itibari ile binalar başlıca enerji kullanıcısı olarak dünyadaki toplam enerjinin \%35'ini kullanacak ve zararlı sera gazı emisyonları salınımında kritik rol oynamaya devam edeceklerdir (Price, 2006: 14).

Avrupa'da binaların \%85'i 20 yıldan ve \%60' 40 yıldan eski olmakla beraber, \%30'u ikinci Dünya savaşı öncesi inşa edilmiş binalardır, bu görece eski ve enerji verimliliği düşük bina stoğunun yarısı önümüzdeki 10 sene içerisinde mevcut Avrupa Birliği Enerji Verimliliği Müktesebatına uygun hale getirilmek üzere yenilenecektir (Bogdan vd., 2011: 9).

Enerjinin her alanda verimli bir şekilde kullanılması ve doğal kaynaklardan elde edilen yenilenebilir enerji, sektörlerin geleceğidir. Almanya'nın Bonn şehrinde yapılan Birleşmiş Milletler Klima Konferansında (COP 23 UN-Klimakonferenz in Bonn, 2017) bütün katılımcı ülkelerin kabul ettiği üzere çevreci teknolojiler ve çevreyi koruma ile ilgili yaptırımlar ve teşvikler önemli oranda arttır1lacaktır (UNFCCC, 2018: 13). Bu da yenilenebilir kaynaklardan üretilen enerji ve enerjinin verimli kullanılmasını sağlayan maliyet etkin akıllı enerji optimizasyon teknolojilerine olan talebi küresel ölçekte arttıracaktır.

$\mathrm{Bu}$ kapsamda binalardan enerji üretilmesi ve üretilen enerjinin verimli bir şekilde kullanılması için gerekli olan alt sistemlerin, bilişim ve haberleşme teknolojileri kullanılarak bütünleştirilmesine yönelik mühendislik çalışmalarının yapılması önemli bir araştırma ve geliştirme alanı olmaktadır.

Günümüzde bütünleşik enerji üretimi ve yönetimine yönelik proje çalışmaları başlatılmış olsa da, bütünleşik sistem entegrasyonunu destekleyen araçlar halen bulunmamakla birlikte, etkin enerji üretimi ve yönetimi için sunulan çözümler bu konuda faaliyet gösteren ve sadece tek bir enerji sistemine (rüzgar, güneş, jeotermal, biyokütle veya enerji saklama sistemleri) odaklanmış olan firmalar tarafindan ortaya konmaktadır. Gelişigüzel kurulmuş olan sistemler, bina sahiplerine bu sistemlerin bütünleşik olarak çalışması ve yönetimi ile ilgili sorunlar yaşatmaktadır. Enerji üretimi, yönetimi ve verimliliği için gerekli olan bütünsel yaklaşımlar, bu sistemlerin tasarım ve yönetim prosedürlerine karmaşık olan bir katman daha eklemektedir (Gökçe Gökçe, 2013).

Bütünleşik olarak ele alınmayan sistem yapıları, yazılım ve donanım entegrasyonu ile ortaya konabilecek pozitif çıktıyı da engellemektedir. Bu eksiklik, bina enerji üretimini ve enerji verimliliğini destekleyen süreçleri ve bu amaçla kullanılabilecek bilgi teknolojileri gelişimini de engellemektedir.

Bu problemin çözümü, sistem analizlerinin yapılması, yeni sistemlerin kurgulanması ve yeni yazılımların ortaya konması ile gerçekleştirilebilir. Binalarda gerekli donanımların kurulması, mevcut sistemlerden veri toplama, karmaşık radyo yayılım özelliklerinin ele alınması, denemeyanılma ile yoğun el işi gerektiren süreçleri kapsamaktadır (Keller vd., 2008: 1). Bu aktiviteler için gerekli olan bilişim teknolojileri desteği ve bu konuda eğitimli bina yöneticileri yeterli değildir (Jagemar vd., 2007: 1).

Son dönemde yaşanan gelişmeler çerçevesinde kablosuz ağlı gömülü teknolojiler birçok alanda ön plana çıkmaktadır. Bu sistemler, ortam izleme ve kontrol uygulamaları için kullanılırlar. $\mathrm{Bu}$ özellikleri maliyetlerinin de ucuz olması nedeni ile binalarda enerji üretim ve kontrol 
performansının ayrıntılı olarak ölçülmesi ve kontrol edilmesi için kullanılabilir olabileceklerini teyit etmektedir.

Özellikle çok boyutlu performans verisi analizleri için kullanılacak verinin toplanabilmesi için gerekli sistem altyapısının kablosuz algılayıcı ve algılayıcı ağ yapıları üzerine kurulması görece yeni bir çalışma alanı olup, binalarda enerji üretimi ve verimliliği için gerekli olan sistem mimarisinin etken elemanlarından biri halini almaktadır.

$\mathrm{Bu}$ doğrultuda, binalarda kullanılan yenilenebilir enerji üretim sistemlerinin optimizasyonu yapılarak enerji plus bina konsepti yani enerjisi kendi kendine yeten ve üretimden kalan fazla enerjiyi şebekeye geri besleyebilen bütüncül bir sistem mimarisi geliştirilmesi amacıyla bina enerji tedariği, kablosuz algılayıcı, bilgi işlem, izleme ve optimizasyon katmaları altında bulunan kablosuz ağlı gömülü teknolojiye sahip donanımlar, bilgi yönetim ve optimizasyon yazılımları TÜBİTAK destekli proje kapsamında özgün olarak tasarlanarak geliştirilmiştir. Sistem iki ayrı test binasında doğrulanmıştır. Çalışmanın devamında geliştirilen sistem, ar-ge süreçleri ve test sonuçları irdelenmektedir.

\section{Proje Amacı}

1507 KOBİ Ar-Ge Başlangıç Destek Programı çerçevesinde 2014- 2017 yılları arasında yürütülmüş olan 7130241 proje numaralı "Binalardan Enerji Üretilmesi ve Akıllı Enerji Yönetimi için Bütünleşik Sistem Mimarisinin Geliştirilmesi" projesi kapsamında entegre yapılar, bütünleşik izleme ve analiz metotları ve karar destek sistemlerini içeren araştırma ve geliştirme faaliyetlerinde bulunulmuştur. Projede önerilen kavram ile binalarda kullanılan şebekeden bağımsız (off-the-grid) yenilenebilir enerji üretim sistemlerinin bütünselliği sağlanmış ve özgün bir bütünleşik bina enerji üretim ve yönetim sistemi geliştirilmiştir.

$\mathrm{Bu}$ amaca ulaşmak için, yenilenebilir enerji üretim sistemleri, ağlı gömülü algılayıcılar, gömülü yazılımlar, kablosuz ağ yapıları, akıllı kontrol algoritmalarından oluşan enerji yönetim aracı, bina enerji performansı izleme aracı, bu araçlardan elde edilen verilerin, veri ambarı entegrasyonunu kapsayan ve sistem işlevselliğini artıran yenilikçi yöntemler içeren bilgi yönetim sistemi, servisler ve mobil uygulamalar ile yürürlükte olan bina enerji düzenlemeleri araştırılmıştır.

Bu proje kapsamında birbirleri ile bütünsel olarak çalışan rüzgâr türbini, fotovoltaik güneş panelleri, bina enerji saklama sistemlerini içeren enerji üretim paketi ve elde edilecek enerjinin binalarda etkin kullanımını sağlayacak, çevre koşulları, bina sistemleri ve enerji üretim sistemleri arasındaki etkileşimi sağlayan ağlı gömülü sistemleri kullanan yazılım ve donanım paketleri geliştirilmiştir.

Bu çalışma sonucunda ortaya konan "EOS Bütünleşik Bina Enerji Üretim Sistemi” açık ve genişletilebilir bilgi alışverişi ile birlikte yeni bir bütünleşik veri toplama ve yönetim sistemi olarak geliştirilmiş; veri ambarı, veri madenciliği, akıllı kontrol ve web hizmeti teknolojilerini kullanarak enerji izleme ve kontrolünün gerçekleştirilmesini sağlamıştır. Geliştirilen sistem kablosuz donanımlar ve senaryo tabanlı algoritmalardan oluşan yazılım yardımı ile bina enerji üretim sistemlerini optimize ederek binaların toplam enerji üretimini arttırmaktadır.

Proje kapsamında geliştirilen sistemin prototipleri, İstanbul Teknik Üniversitesi Teknopark bünyesinde yer alan EOS İstanbul Sürdürülebilir Enerji Çözümleri A.Ș. firmasına ait laboratuvar ve İstanbul ili Bahçeşehir semtinde yer alan konut olarak kullanılan test binasında, 2017-2019 yılları arasında test edilmiştir. Yapılan testler sonucunda geliştirilen sistemin farklı mevsimsel koşullar altında en düşük $10.1 \mathrm{kWh}$ ile en yüksek $24.36 \mathrm{kWh}$ aralığında enerji üretimi sağladığı kayıt altına alınmıştır. 


\section{Sistem Mimarisi}

Geliştirilen sistem mimarisi (Şekil 1), farklı yenilenebilir enerji üretim teknolojilerine yönelik olarak bütünleşme kavramlarını, bütünsel izleme ve analiz yöntemlerini, yaşam döngüsüne yönelik karar destek süreçlerini kapsayan bilgi ve iletişim teknolojilerini desteklemektedir.

"EOS Bütünleşik Bina Enerji Üretim Sistemi”, aşağıda verilen yaklaşımlar ve geliştirme süreçleri temelinde oluşturulmuştur:

1. Kullanıcı ve sistem gereksinimlerine göre bütünleşik yapıda çalışabilen yenilenebilir enerji üretimine yönelik uygulamaların gelişimine olanak tanıyan yenilikçi bir sistem geliştirme platformunun oluşturulması,

2. Mevcut bileşenlerin optimizasyonunu hedefleyen özgün bir modüler modelleme yaklaşımının teşkil edilmesi,

3. Gerçek zamanlı veri toplama ve kontrol amaçlı kablosuz ağl1 gömülü teknolojiler içeren algılayıcı ve kontrol ünitelerinin donanıma özel gömülü yazılımlarını da içerecek şekilde özgün olarak geliştirilmesi,

4. Veri ambarı teknolojilerini, veri madenciliğini ve web tabanlı hizmetleri kullanarak enerji performansı izleme ve akıllı kontrol için gerekli çok boyutlu bilgi yönetim platformunun oluşturulması,

5. Farklı veri tiplerine sahip teknolojilerin ve araçların birlikte çalışabilirliğini kolaylaştıran Çıkarma, Dönüştürme ve Yükleme (ÇDY) aracı isimli açık ve genişletilebilir bir veri alışverişi yönteminin geliştirilerek teşkil edilmesi,

6. Farklı kullanım koşulları ve senaryoları için bina enerji üretim sistemlerini optimize eden Akıllı Kontrol aracının teşkil edilmesi ve,

7. Birden fazla paydaş için bağlama duyarlı, web tabanlı, grafiksel kullanıcı ara yüzlerinin oluşturulması.

Önerilen kavram, binalar için yenilenebilir enerji üretim sistemlerinin yüksek verimlilik temelinde optimum entegrasyonunu ve kontrolünü sağlayan birbirleri ile bütünsel fonksiyona sahip dört farklı katmandan oluşmaktadır. Bunlar aşağıda verilmiştir.

1. Bina Enerji Tedariği Katmanı,

2. Kablosuz Algilayıc1 Katmanı,

3. Bilgi İşlem Katmanı,

4. İzleme ve Optimizasyon Katman1. 

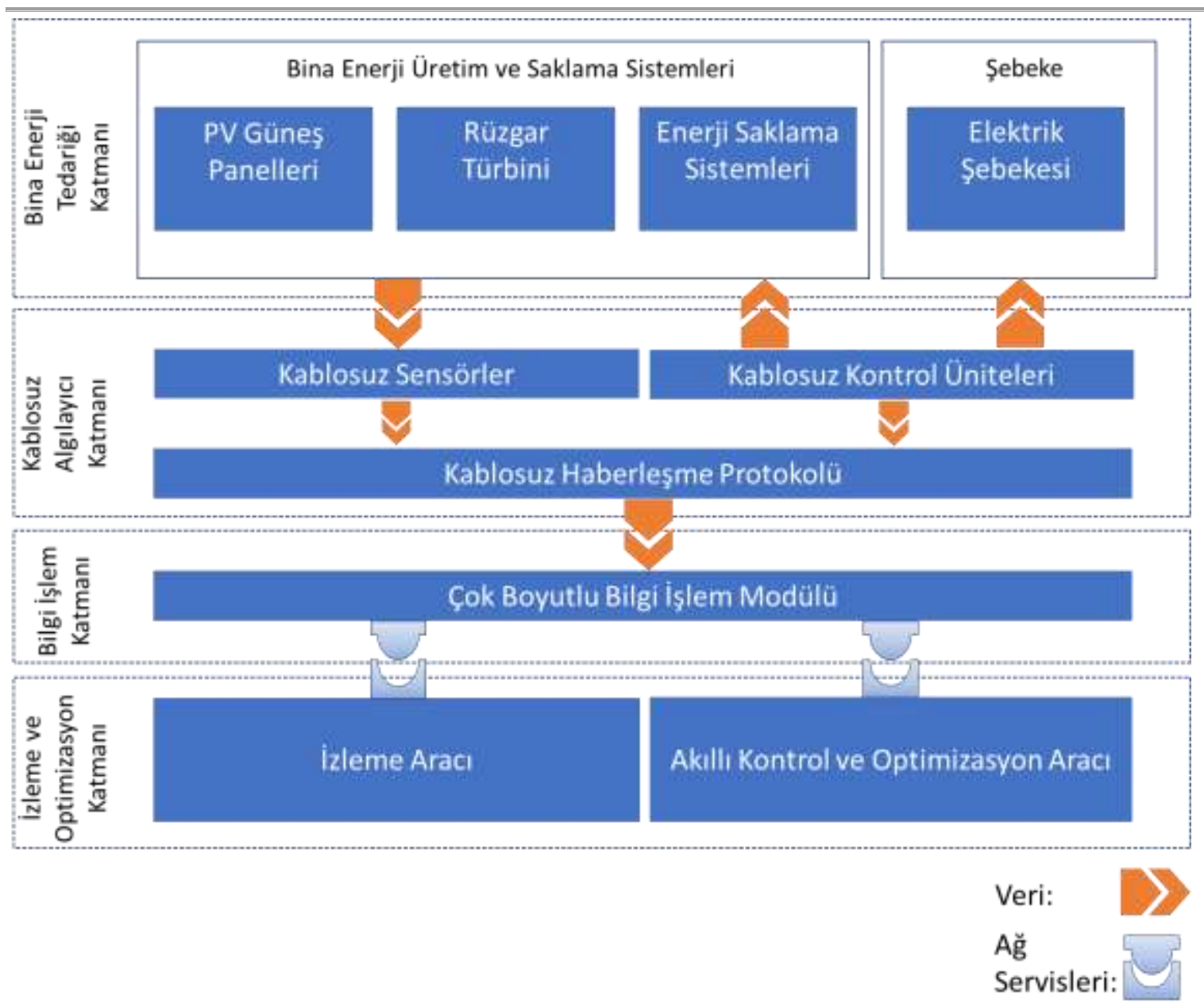

Şekil 1: EOS Bütünleşik Bina Enerji Üretim Sistemi Mimarisi.

\section{Bina Enerji Tedariği Katmanı}

$\mathrm{Bu}$ katman, farklı tipte yenilenebilir enerji üretim sistemlerinin birlikte çalışabilirliği ve optimizasyonu, konutlar için küçük ölçekli çeşitli yenilenebilir enerji üretim teknolojilerinin planlanması ve yerinde uygulanmasını kapsamaktadır. Projenin bu safhası binalarda şebeke dışı yenilenebilir enerji üretimi ve depolanması için rüzgar enerji türbini, PV güneş enerji panelleri, enerji saklama sistemleri, enerji talebi ve şebeke tedarik modelleri de dahil olmak üzere ihtiyaç analizine dayalı entegre bir yapının tasarlanması, geliştirilmesi ve uygulamasını içerir. Bu katman bina enerji üretim ve saklama sistemleri ile elektrik şebekesinden oluşmaktadır.

\section{Bina Enerji Üretim ve Saklama Sistemleri}

Günümüzde, binaların enerji ihtiyacını karşılamaya yönelik kurulan şebekeden bağımsız yenilenebilir enerji teknolojileri genellikle güneş veya rüzgar gibi tek bir yenilenebilir kaynaktan beslenen enerji üretimini ele almaktadır. Örnek olarak bina tipi rüzgar türbininden veya binaların çatılarında konuşlandırılan fotovoltaik güneş panellerinden elde edilen enerji, bina tipi akülerde saklanır ve bina enerji ihtiyacının bir kısmı buradan karşılanır. Farklı teknolojilerin entegrasyonunu içeren sistemler, genellikle bu sistemlerin üreticilerinin kendi belirlediği teknik ve ticari ürün tercihlerine göre şekillenmektedir. 
$\mathrm{Bu}$ nedenle, farklı sistemlerin entegrasyonunu destekleyen optimum süreçlerin tanımı, örneğin; ortak bir enerji depolama sistemini besleyen bina tipi rüzgar türbinleri ve fotovoltaik güneş panellerinin entegrasyonu ile rüzgar hızı, gün ışığı süresi gibi çevresel koşullar temelinde enerji üretimi optimizasyonun sağlanması, bütünsel, modüler bir yaklaşımın ön koşullarından biri olarak kabul edilebilir.

Bu araştırmada, farklı enerji üretim sistemlerinin optimum olarak entegre edilebilmesi için, aşağıda anlatılan sistemler ile ilgili gereklilik analizleri yapılmış ve testler için uygun olan enerji üretim sistemleri seçilmiştir. Bu analiz sonuçları, sistem entegrasyonu için gerekli olan donanım ve yazılım geliştirme süreçlerinde girdi olarak kullanılmıştır.

\section{Bina tipi küçük ölçekli Rüzgar Türbinleri}

Çalışmanın bu safhasında gereklilik analizlerinin yapılması amacıyla, binalar için farklı tiplerde rüzgar türbinleri incelenmiştir. Uygulama senaryolarımızla uyumlu olarak rüzgar enerjisi üretimini sağlamak ve optimize etmek için 1000W 24V-DC pil şarjlı 3 kanatlı rüzgar türbini tipi seçilmiştir. Bu tip rüzgar türbinlerinde kesinti hızı, sürekli üretimi kolaylaştırmak için düşüktür. 100 $\mathrm{km} / \mathrm{s}^{\prime}$ i aşan rüzgar hızlarında dahi elektrik üretimi yapılabilmektedir. Bu tür bina tipi rüzgar türbinleri genellikle tek bir eksenel akımlı, sabit mıknatıslı, firçasız alternatörden oluşur. Üç kanatlı tasarım, rotorun hızını kontrol eden, kanat türbülansı yoluyla çevreye rahatsızlık veren ses ve gürültü olmadan hız kontrolü sağlayabilen kendi kendini düzenleyen bir aerodinamik yapıyı desteklemektedir. Kanat çapı bu tip rüzgar türbinleri için 1,5 m'dir (Abhishikta vd., 2016).

\section{Fotovoltaik hücrelerden oluşan Güneş Panelleri}

Bu çalışmada, dört farklı fotovoltaik güneş paneli tipi ele alınmıştır.

(1) Polikristalin hücrelerden oluşan güneş panelleri: Bu tip panellerin güneş 1şığından elektrik enerjisine çevrim verimliliği ölçütü olan dönüşüm verimliliği \%13-\%15 aralığındadır ve mevcut uygulamalarda en çok kullanılan panel cinsidir. Dezavantaj olarak, polikristalin hücreli panellerin 50 santigrat derecelik panel ısısının altında kalan sıcaklıklarda dönüşüm verimliliği \%20 oranında düşmektedir.

(2) Monokristalin hücrelerden oluşan güneş panelleri: Bunlar telekomünikasyon gibi sektörlerde kullanılan dönüşüm verimliliği polikristaline göre daha yüksek olarak \%14 - \%17,5 aralığında bulunan ve verimliliği, panel ısısının gerekli olan ısının altına inmesi ile \%10 ile \%15 arasında değişen oranlarda azalan güneş panelleridir.

(3) Amorf hücrelerden oluşan paneller: Birçok taşınabilir alette yıllardır kullanılan ve dönüşüm verimliliği \%5-\%7 arasında bulunan panellerdir. Diğer panellerin aksine bir avantaj olarak bu panel tiplerinde herhangi bir performans kaybı yaşanmamaktadır.

(4) İnce film hücreli CIGS (Copper, Indium, Gallium, diSelenide) teknoloji panelleri: İnce film fotovoltaik teknolojili panel tipleri olarak ta sinıflandırılan bu paneller esnek, dayanıklı ve bahsi geçen diğer güneş hücreleri le karşılaştıllıdığında daha yüksek verimliliğe sahiptir. Optik yoğunlaştırıcı sistemler ile birlikte kullanıldığ 1 durumlarda \%30'a varan oranlarda dönüşüm verimliliği sağlamaktadır (Donne 2013:4).

Güneşten elde edilecek enerji ile ilgili diğer önemli bir sistem enerji pillerini doldurmak üzere akımı ileten güneş paneli şarj kontrol cihazıdır. Mevcutta kullanılan üç ana tip güneş paneli şarj kontrol cihazı mevcuttur:

(1) Standart k1sa faz kontrolör,

(2) Aşamalı kontrolör,

(3) Maksimum Güç Noktalı İzleme kontrolörü (MPPT). 
İlk iki kontrolör panel enerjisinin \%70'ni bataryalara iletirken güneş panellerinin voltajını düşürür fakat akımı arttırmaz. MPPT kontrolörü görece yeni bir teknoloji olup \%96 ve üstünde bir çıktı sağlar. Buradaki diğer kritik bir konu ise kontrolörün bulunduğu noktadır. Güneş paneli kablosunun çıkışında yer alan enerji saklama sisteminin (akünün) üzerinde yer alan kontrolör akülerin tümüyle doldurulmasını sağlar. Panel rölatif çıtılarının birbirleri ile kıyaslanması sonucunda ortaya çıkan akülerin doldurulması için gerekli olan akımın ortalama $13.5 \mathrm{~V}$ olması gereklidir. Yapılan gereklilik analizleri sonucunda bu bilimsel çalışmada mevcut sistemler incelenmiş, verimlilik, maliyet ve ulaşılabilirlik kıstasları baz alınarak polikristalin güneş panelleri ve MPPT kontrolleri kullanılmıştır.

\section{Enerji Saklama Sistemleri}

Enerji saklama sistemleri ile ilgili iki farklı tipte akü sistemi incelenmiş̧tir:

(1) Kurşun asitli, uzun döngülü aküler: Bu akü tipleri, elektrik akımını şarj süreleri haricinde uzun sürelerde saklayabilen, ağır gözeneksiz kurşun plakaların sülfirik asit solüsyonunda gömülü olduğu ve uzun süre şarj edilmemeye karşı dirençli olan akülerdir.

(2) Nikel Alaşımlı Aküler Nikel Kadmiyum (NiCad) ve Nikel Demir Aküleri: Nikel alaşımlı plakaların alkalin solüsyonu içerisine batırılması ile elde edilen akülerdir. Nikel ve Kadmiyum kullanımı kaynaklı olarak maliyetleri kurşun asit tiplere göre daha yüksektir. Toplam amper saat kapasitesine göre daha fazla akımı deşarj edebilirler. Negatif sıcaklık katsayısı yüksektir. Nikel alaşımlı aküler düşük 1sılarda daha iyi çalışırlar. Akü iç sıcaklığı yükseldikçe verimliliği düşmektedir. $\mathrm{Bu}$ tip aküler tamamen şarjsız bırakılamazlar ve doluluk oranları devamlı takip edilmelidir. Bu nedenle, karmaşık şarj sistemlerine gerek duyulmaktadır.

Yapılan gereklilik analizleri temelinde, bu bilimsel araştırma geliştirme projesi kapsamında kurşun asitli aküler diğer akü tiplerine göre daha maliyet etkin olmaları ve yüksek güçler altında şarj deşarj döngüsüne sahip bina enerji çözümlerine daha uygun olmaları nedeniyle kullanılmıştır.

Akü kümesi enerji tedarik sistemlerinin temel elemanıdır ve bina için gerekli olan kesintisiz enerjiyi sağlamaktadır. Akü kümesiz, binanın tüm elektrik sistemi yenilenebilir enerji sistemlerinin devreden çıkması ile kısıtlanmış olur. Rüzgar türbini, rüzgar hızının artması, azalması veya kaybolması ile devamlı surette güç değişimlerine (dalgalanmalara) maruz kalır. Geceleri, sadece güneş enerjisi sistemi bulunan bir bina, elektrik enerjisi üretemez. Bu nedenle problemsiz bir şekilde devamlı surette elektrik sağlamak için şebeke bağlantısı ile akü küme bağlantılarının da yapılması gerekir. Bu entegrasyon bina için gerekli olan enerjinin hava koşullarından bağımsız olarak uygun enerji fiyatları ile tedarik edilmesine de olanak sağlamaktadır.

$\mathrm{Bu}$ çalışmada, sistem üç bağımsız kurşun asitli akü kümesine göre tasarlanmıştır. Bu akü kümeleri bina tipi rüzgar türbinine, fotovoltaik güneş panellerine ve merkezi elektrik şebekesine bağlanmıştır. Böylece rüzgar türbini ve güneş panelleri akü kümelerini mevcut enerji ihtiyacından bağımsız olarak şarj edebilecekler ve az enerji kullanımı sonucu atıl kalan enerji, yüksek enerji tüketim hallerinde kullanılabilecektir.

Proje kapsamında kablosuz ağlı gömülü teknolojilere sahip algılayıcılar özgün olarak tasarlanmış ve geliştirilmiştir. Bu kablosuz algılayıcılar, anlık enerji üretimin miktarlarını ve akü kümesinin şarj durumunu gerçek zamanlı olarak izlemekte, geliştirilen akıllı kontrol yazılımı ise bina enerji kullanımına göre batarya kümelerinin doluluk oranına karar vermektedir. Buna göre şebekeye anlık olarak verilecek elektrik miktarı da tespit edilebilmekte ve proje kapsamında geliştirilen kontrol ünitesi donanımı ile atıl enerjinin şebekeye verilmesi, şebeke altyapısının uygunluk durumuna bağlı olarak satışı gerçekleştirilebilmektedir. Ayrıca, geliştirilen kontrol ünitesi akü kümelerinde herhangi bir problem çıkması halinde veya akü kümelerindeki enerjinin talebi karşılamaması durumunda bina ile elektrik şebekesi bağlantısını direkt olarak sağlamaktadır. 
Bu çalışmada akü kümelerinden elde edilecek olan doğru akım, binada kullanılan elektrikli gereçler için alternatif akıma eviren Abax marka DC-AC invertör kullanılmıştır. Kullanılan invertör sistem AC-DC düzenleyicisine de sahiptir. Alternatif akım şebeke gücünü akü kümelerinin şarj edilmesi için doğru akıma evrilmesi içinde kullanmaktadır.

\section{Kablosuz Algılayıcı Katmanı}

Teknolojinin görece güvenilir hale gelmesi ve maliyetlerin azalması gibi son dönemde yaşanan gelişmeler çerçevesinde kablosuz ağlı gömülü teknolojilere sahip algılayıcı (sensör) ve kontrol ünitelerinin, ortam izleme ve kontrol uygulamaları için kullanılabilir olması önem kazanmıştır. Bu özellikleri maliyetlerinin de düşük olması nedeni ile binalarda enerji performansının ayrıntılı olarak ölçülmesi ve optimizasyon amaçlı kontrol edilmesi için kullanılabilir olabileceklerini de teyit etmektedir. Özellikle çok boyutlu veri analizleri için gerekli olan enerji ve ortam verilerinin elde edilebilmesi için gerekli sistem altyapısının kablosuz sensör ve sensör ağ yapıları üzerine kurulması yenilikçi bir çalışma alanı olup, binalarda verimli enerji üretimi için gerekli olan sistem mimarisinin etken elemanlarından biri halini almaktadır.

Kablosuz sistemler özellikle düşük maliyetli kurulum ve bakım esnekliği, geleneksel kablolu Bina Yönetim Sistemleri için bir alternatif oluşturmaktadır. İlave olarak mevcut binalarda herhangi bir inşa faaliyeti ve onarıma ihtiyaç olmadan sistemin sorunsuzca kurulması ve mevcut kablolu sistemlere adapte olabilme yeteneği sayesinde teknolojik ve pratik anlamda bir üstünlük getirmektedir. Bu avantajlarına rağmen özellikle büyük ölçekli uygulamalarda, sinyal geçirgenliği, bilgi iletim gecikmeleri, mesaj kayıpları ve güvenilirlik gibi bazı sorunlarla da karşılaşılmaktadır.

Geçmiş yıllarda bu konuda çeşitli çalışmalar sürdürülmesine rağmen kablosuz ağ yapıları, kablosuz sensörler ve bunların bina otomasyon sistem uygulamaları ile ilgili çalışmalar yeterli değildir (Gökçe, 2011). Son dönemde özellikle Avrupa Birliği tarafından ortaya konan enerji verimlilik hedefleri doğrultusunda kablosuz teknolojilerin bu yöndeki çalışmalara uyarlanmas1 amacına hızlı bir eğilim söz konusudur. Geçmiş dönemde Avrupa'da yürütülen ve tamamlanmış olan çalışmalardan konu ile ilişkili olanları şunlardır; GAWIND (Gawind, 2006) geniş tabanlı kablosuz yayın olanağını desteklemek amacı ile yeni yazılım araçları ve tasarım yöntembiliminin geliştirilmesi ki burada odaklanılan nokta grid teknolojilerinin kullanılmasıdır, FEEDNET-BACK (Feednet-back, 2007) ağ kontrolü için ortak bir tasarım çerçevesini destekleyen yeni bir yazılımın ortaya konması, Buildwise (Buildwise, 2011) kablosuz sensörlerle Bina Enerji Performansının ölçülmesi için gerekli olan bilginin bina kullanım alanlarından ve bina ekipmanlarından elde edilmesi ve bunun son kullanıcıya sunulması, ITOBO (ITOBO, 2012) kablosuz sensörlerle binalardan elde edilmiş olan bilginin, bina operasyonlarının optimize edilmesi için kullanılması gibi projeler örnek olarak verilebilir.

$\mathrm{Bu}$ projede kullanılan kablosuz sensör ağ1, düşük güçte IP (İnternet Protokolü) (IEEE 802.15.4 böyle bir bağlantıyı sunar) iletişimini sağlayan IETF 6LoWPAN (RPC 4944) standardı üzerine kurulmuştur. Bu standard üzerine kurulu olan kablosuz sensör ağı diğer IP ağlarına bir veya birden fazla yönlendirici ile Ethernet, Wi-fi veya mevcut $2 \mathrm{G}$ cep telefonu şebekesi üzerinden paket anahtarlamalı olarak veri iletimi sağlayan GPRS (General Packet Radio Service) teknolojileri kullanarak gerekli bilgi paketlerini göndermektedirler. IP mimarisi genel olarak benimsenmiş olup sunmuş olduğu açıklık, esneklik, ölçeklenebilirlik ve yönetilebilirlik özellikleri ile entegrasyon için uygun bir protokoldür. Birçok endüstri standartı ki bunlar BACNet, LonTalk, CIP ve SCADA gibi Ethernet üzerinden TCP/IP veya UDP/IP teknolojilerini kullanırlar.

$\mathrm{Bu}$ proje kapsamında geliştirilen kablosuz sensörler sıcaklık, nem, ışıma oranları gibi çevresel parametreleri izlemek, ölçmek ve elektrik enerjisi miktarı ölçümlerinde kablosuz sayaç olarak kullanılmak üzere geliştirilmişlerdir. Tablo 1'de bu proje kapsamında geliştirilmiş kablosuz ağlı gömülü teknolojilere sahip donanımların listesi verilmiştir. 
Proje kapsamında özgün olarak tasarlanarak geliştirilen donanımlar üç ana bileşenden oluşmaktadır: (1) sensör ölçüm arayüzü nem, 1sı, 1şık, rüzgar ve elektrik enerjisi miktarı gibi fiziksel özelliklerin ölçülmesi amacıyla, (2) radyo arayüzü diğer sensörlerle iletişim amacıyla, (3) merkezi işlemci (CPU), hesaplamalar ve diğer iki bileşen arasındaki veri alışverişinin sağlanması içindir. Geliştirilen panolarda Atmega1281 MCU ve EM2420 radyo yongaları kullanılmıştır. Bunun da ötesinde elektrik sayaçları ile birlikte çalışacak AC ve DC yük kontrolüne yönelik (aç/kapa) bir arayüz de bulunmaktadır. Geliştirilen platform b6LoWPAN standartını kullanmaktadır. Atheros CM9 Wi-Fi kartları ve tek bir IEEE802.15.4 node içeren PC panoları tüm sistemler için tesis edilmiştir. Tablo 1'de proje kapsamında geliştirilen donanımlar ve işlev tanımları verilmiştir.

Tablo 1: EOS Entegre Enerji Üretimi Sistemi Bileşenleri Listesi.

\begin{tabular}{|c|c|c|}
\hline No & Donanım ve Yazılım & Tanım \\
\hline 1 & EOS Algılayıcı & $\begin{array}{l}\text { Isı, 1şıma, nem, rüzgar hızı seviyelerinin gerçek zamanlı olarak ölçülmesi } \\
\text { için kullanılır. Güneş ve rüzgardan elde edilebilecek enerji miktarlarının } \\
\text { analiz ve tahmin edilmesi amacıyla oluşturulan algortimalara veri } \\
\text { sağlamaktadır. }\end{array}$ \\
\hline 2 & $\begin{array}{l}\text { EOS Aç-Kapa } \\
\text { Kontrol Ünitesi }\end{array}$ & $\begin{array}{l}\text { Güneş ve rüzgardan elde edilen enerji değerleri ve bina enerji kullanım } \\
\text { yoğunluğuna göre geliştirilen optimizasyon yazılımı tarafindan verilen } \\
\text { kararlar doğrultusunda enerji saklama modülü şarjı, şebekenden enerji } \\
\text { kullanımı ve enerji tedariği karar süreçlerinin optimize edilmesi amaciyla } \\
\text { kullanılmıştır. }\end{array}$ \\
\hline 3 & EOS Sayaç & $\begin{array}{l}\text { Elektrik üretim ve kullanım miktarlarının gerçek zamanlı ölçülmesi için } \\
\text { kullanılır. }\end{array}$ \\
\hline 4 & $\begin{array}{l}\text { EOS Kelepçeli } \\
\text { Sayaç }\end{array}$ & $\begin{array}{l}\text { İstenilen sistemin ve alanın elektrik sarfiyatının gerçek zamanlı ölçülmesi } \\
\text { için kullanılır. Rüzgar türbini, güneş panelleri ve şebeke ana akım } \\
\text { kablolarına kelepçeli sayaç vasıtası ile bağlanılır. }\end{array}$ \\
\hline 5 & $\begin{array}{l}\text { EOS Sinyal A ̆ğ } \\
\text { Yönlendiricisi }\end{array}$ & $\begin{array}{l}\text { Sistemde kullanılan algılayıcı ve kontrol ünitelerinin birbiri ile kablosuz } \\
\text { haberleşmesini sağlar. }\end{array}$ \\
\hline
\end{tabular}

\section{Bilgi İşlem, İzleme ve Optimizasyon Katmanları}

Proje kapsamında bilgi işlem, izleme ve optimizasyon katmanları altında özgün olarak geliştirilen yazılım araçları, binalardan sıfır emisyonlu enerji üretilmesi için gerekli olan yenilenebilir enerji sistemlerinin entegrasyonunu ve uygun altyap1 bulunduğu takdirde merkezi elektrik şebekesine geri verilmesi/satılması amacıyla bağlantısını, bu sistemlerin kullanıcı ihtiyaçları ve çevresel faktörler doğrultusunda optimum kontrolünü sağlamaktadır.

Bunun sağlanabilmesi için yenilikçi bir model temelli sistem geliştirme yaklaşımı ele alınmıştır. $\mathrm{Bu}$ yaklaşımla, kullanılacak sistemlerin işlevselliğini belirten gereklilik analizleri tamamlanmıştır. $\mathrm{Bu}$ analizler çerçevesinde kaynak kodları her bir katmanda bulunan yazılım araçları ve donanımların gömülü yazılımları için, belirlenen gereklilikleri karşılamak ve oluşturulan yapıdaki sistemlerin optimum entegrasyonuna yönelik tasarlanarak geliştirilmiştir. Kullanılan her bir sistemin fonksiyonları, gereklilik analizleri, yazılım bilgisi ve elektronik sistem tanımları özgün olarak geliştirilen veri ambarında saklanmıştır. Veri ambarı sistem bileşenlerinin bilgilerini ilgili geliştirme iş paketilerinde çoklu kullanıcılar tarafından eş zamanlı ulaşılabilmesi amacıyla işlemektedir.

Bunu izleyen süreçte belirlenmiş gereklilikler temelinde rüzgar türbininin, güneş panellerinin ve enerji saklama sistemlerinin (akü kümesi) bütüncül bir yaklaşımla optimum çalışması ve mevcut elektrik şebekesiyle ilişkileri için, aşağıda kısaca işlevselliği tanımlanmış olan yazılım araçları tasarlanmıştır. Bu yazılım araçları yenilenebilir enerji kaynaklarından elde edilen enerjinin kısıtlara bağı olarak hangi durumlar altında akü kümelerinde saklanması gerektiğini ve bu 
sistemler arasındaki optimizasyonu desteklemektedir. Ayrıca, bu yazılımlar yeterli elektrik enerjisinin üretilmediği durumlarda, akü kümelerinin otomatik olarak devreye alınmasını kontrol etmektedir. Karbon emisyonlarını da dikkate alarak sistemlerin maliyet etkin bir şekilde çalışmasını sağlamaktadır. Geliştirilen karar destek algoritması ve kablosuz ağlı gömülü donanımlar ile akülerin hangi kaynaktan ne zaman doldurulacağına karar verilebilmektedir. Bu yazılım aracı akülerde yeterli enerji bulunduğunda, binanın ihtiyaç duyduğu enerjiyi sağlamaktadır ve akülerdeki kritik enerji seviyesine gelindiğinde şebeke elektiğine geçilecek şekilde tasarlanmıştır. Bunun da ötesinde yenilenebilir enerji seviyesi yetersiz olduğunda şebekedeki enerji kullanımı ve enerji fiyatları düşük olduğunda akülerin şebeke elektriği ile şarj edilmesini de mümkün kılacak yazılım donanım çözümlerine de sahiptir.

Enerji üretimi, bina enerji kullanımı planları doğrultusunda, üretilen fazla enerjinin şebekeye satışını da desteklemektedir. Bu yazılımlar çok boyutlu enerji izleme, analiz ve optimizasyon sistemlerini içeren 3 temel ve tamamlayıcı bileşen üzerine inşa edilmiştir. Bunlar: (1) Çok boyulu bilgi işlem modülü, (2) Akıllı kontrol ve optimizasyon aracı, (3) İzleme aracıdır.

\section{Çok Boyutlu Bilgi İşlem Modülü}

Proje kapsamında tasarlanarak geliştirilen bilgi işlem modülü, bina enerji performans verilerinin çok boyutlu analizi yapılarak karar süreçlerinin desteklenmesi için kablosuz sensör ve sayaçlardan binada uygulanan enerji üretim sistemleri fonksiyon durumları ve enerji üretim miktarları ile ilgili farklı tiplere sahip karmaşık verilerin toplanması, saklanması ve analiz edilmesi amacıyla kullanılmaktadır. Bu amaçla, MySQL platformunda çok boyutlu bir veri ambarı kurularak optimizasyon ve izleme katmanları için gerekli olan harekete geçilebilir bilgi küpleri oluşturulmaktadır. Optimizasyon aracının enerji verimlilik algoritmaları için gerekli olan çoklu kriterleri içeren veri küpleri gerçek zamanlı olarak oluşturulabilmektedir. Ayrıca, farklı kullanıcı ihtiyaçları doğrultusunda oluşturulan veri küpleri bağlama duyarlı grafiksel kullanıcı arayüzleri ile son kullanıcıya gerçek zamanlı izleme amaçlı gösterilebilmektedir.

Bilginin veri ambarına devamlı ve düzenli olarak yüklenmesi gereklidir. Bunun yapılabilmesi için bilginin bir veya daha fazla operasyonel sistemden elde edilmesi ve bilgi veri ambarına yüklenmesi gereklidir. Bilginin kaynak sistemlerinden elde edilmesi ve bunun veri ambarına yüklenmesi sürecine ÇDY-Çıkarma, Dönüştürme ve Yükleme (ETL-Extraction, Transformation, and Loading) denir (Loney, 2004). Projenin sistem mimarisi için ihtiyaç analizi doğrultusunda özgün olarak geliştirilen ÇDY aracı farklı sistem bileşenlerinden toplanan farklı verilerin, bilgi işlem modülünde bulunan durumsal veri tablolarına doldurulması amacı ile kullanılmaktadır. Durumsal veri tabloları uzun dönemli dinamik verilerin örnek olarak ölçüm bilgilerinin saklanması için oluşturulmuştur. Aynı zamanda geliştirilen ÇDY aracı boyutsal bilgi tablolarının doldurulması amacı ile de kullanılmışıtır. Boyutsal bilgiler statik bilgiyi içerir, buna örnek olarak binada kullanılacak bina tipi rüzgar türbinleri, güneş panelleri, enerji saklama sistemleri, havalandırma, 1sıtma ve soğutma sistem bilgileri verilebilir.

Veri ambarı operasyonel veri yerine rafine edilmiş özet bilgiyi saklar ve işler. Bu rafine özet bilgi zaman aralıkları başta olmak üzere çoktu boyut ve kriterleri içererek oluşturulan veri tabanı sorgularına etkin cevaplar verebilir. Örnek olarak "Belirlenmiş bir binada kurulu rüzgar türbininden, bina dışı rüzgar yönü kuzey güney istikametinde ve hızı $40 \mathrm{~km} / \mathrm{saat}$ olduğunda üretebileceği enerji miktarı ne kadar olur?" benzeri veri tabanı sorgulamaları cevaplanabilir. Sistemin veri ambarı bileşeninin amacı: (1) farklı kaynaklardan (kablolu, kablosuz sensörlerden ve sayaçlardan) elde edilen ve zamana bağlı olarak değişkenlik arzeden dinamik verinin toplanması, (2) Dinamik verinin boyutsal bilgi ile bütünleştirilmesi ki boyutsal bilgi genellikle sı modifiye edilmeyen ve dinamik bilgiyi kategorize eden bilgidir ve (3) çok boyutlu bilginin karar süreçlerini desteklemesi amaciyla toplulaştırılarak gerekli veri küplerinin oluşturulmasıdır. (Gökçe, 2017).

\section{İzleme Aracı}


Proje kapsamında geliştirilen, bağlama duyarlı grafiksel kullanıcı ara yüzlerinin amacı bina enerji kullanıcılarına, şebeke operatörlerine ve enerji üreticilerine fonksiyonları ile ilgili olarak bina enerji üretim performansının gösterilmesidir. Bina enerji performansı takip araçları oluşturulma süreci son kullanıcılar için oluşturulacak grafiksel arayüzlerin görsel tasarımını ve yazılım geliştirme süreçlerini içermektedir. Bu doğrultuda karmaşık yapısal sorgulama dilleri (SQL- Structured Query Language) tanımlamalarına ihtiyaç duymayacak şekilde son kullanıcılar için otomatik sorgulamayı kolaylaştıran Java programlama dilinde ve SOA (Service Oriented Architecture) tabanlı grafiksel kullanıcı arayüzleri geliştirilmiştir.

\section{Akıllı Kontrol ve Optimizasyon Aracı}

Bilgi işlem modülü tarafından oluşturulan kullanıma hazır veri küpleri, akıllı kontrol modülü algoritmalarının içinde bina enerji üretiminin kontrol ve optimizasyonunu sağlamak amaçlı kullanılmaktadır. Akıllı kontrol modülü; (1) bina tipi rüzgar türbinleri, (2) fotovoltaik güneş panelleri ve (3) enerji saklama sistemleri (aküler) için oluşturulan operasyon senoryolarını içeren akıllı kontrol algoritmalarını içermektedir. Bunun yanında bilgi işlem modülü ile iletişim halinde bulunarak kontrol parametrelerinin hesaplanmasını ve bu verilerin kontrol amaciyla kablosuz ağlara aktarılmasını sağlamaktadır.

Senaryo tabanlı algoritmalar içeren akıllı kontrol ve optimizasyon aracı, tanımlanmış rüzgar ve güneş sistemleri için gerekli olan optimizasyon algoritmalarını ve kontrol parametrelerini hesaplamak için bilgi işlem modülü ile etkileşime girer.

Bilgi işlem modülünün oluşturduğu harekete geçirilebilir bilgi içeren veri küpleri, akıllı kontrol ve optimizasyon aracı yazılımı tarafindan analiz edilir. Analiz algoritmalar tarafindan kullanılır ve verilen karar komutu kontrol ünitelerini belirlenen enerji üretimine yönelik optimizasyon senaryoları tabanında harekete geçirmek için kablosuz haberleşme protokolüne aktarılır. Kablosuz haberleşme protokolü tarafindan gönderilen komutlar ile kablosuz kontrol üniteleri ilgili bina enerji üretim sistemini kontrol eder.

\section{Sistem Geliştirme Süreçleri}

TÜBİTAK destekleri ile yürütülen bu ar-ge projemizde, geliştirilen sistem mimarisi çerçevesinde, "EOS Bütünleşik Bina Enerji Üretimi Sistemi” geliştirilmesine yönelik altı aşamadan oluşan bir süreç ele alınmıştır.

Çalışmanın birinci aşamasında "Bütünleşik Bina Enerji Üretim ve Yönetim Sistemlerinin" teşkili için gerekli olan şebekeden bağımsız yenilenebilir enerji üretim sistemlerinin gereklilik analizleri tamamlanmıştır. Büyük ölçekli karmaşık ağ yapıları, ağlı gömülü sistemler, mevcut ağ tabanlı servisler ve mobil uygulamalar ile ilgili literatür taraması ve teknik araştırmalar yürütülerek, planlanan sistem mimarisi kurulumu için gerekli olan bilgilerin elde edilmesine ve önerilen sistem mimarisinin teşkiline yönelik spesifikasyonların oluşturulması tamamlanmıştır. İncelenen parametreler: (1) Bina enerji üretim sistemleri ve mevcut uygulamalar, (2) Büyük ölçekli karmaşık ăg yapıları teknolojileri ve uygulama alanları, (3) Mevcut ăg tabanlı servisler ve mobil uygulamalar ile bunların benzer uygulama alanları, (4) Entegre sistem yapıları ve benzer uygulamalardır.

Çalışmanın ikinci periyodunda projede kullanılan bina enerji üretim sistemlerinin teşkil edilmesi ve test binasındaki konfigürasyonu, bu sistemlerin birbirleri ile entegrasyonu için gerekli analizleri ve ilgili spesifikasyon çalışmalarını içermektedir. İncelenen parametreler: (1) Enerji üretim sistemlerinin binalara adaptasyonu ve sistemlerin birlikte çalışma esnasında gösterdiği tepkimeler, binaya olası etkiler, (2) Enerji üretim sistemlerinin entegrasyonu ile elde edilebilecek enerji çıktısının simülasyon ortamında analizi, elde edilebilecek enerji miktarı, enerji tasarrufuna etkileridir.

Projenin üçüncü safhası sensör ve ağ yapıları ile ilgili spesifikasyon çalışmalarını ve sistem mimarisi için gerekli olan kablosuz ağl1 gömülü teknolojilere sahip algılayıcılar ve kontrol 
sistemlerinin özgün olarak tasarımını içermiştir. İncelenen parametreler: (1) Kablosuz sistemlerin uygulama alanları ve önerilen sistem için kullanımı, (2) Algılayıcı ve kontrol donanım ağlarının önerilen sisteme adaptasyonu, (3) Heterojen kablosuz algılama esasları ve gereklilikleridir.

Planlanan iş programına göre projenin dördüncü safhasında, önerilen bütüncül sistem mimarisinde kullanılan enerji üretim sistemleri ile kablosuz ağlı gömülü donanımlar için gerekli olan komponentlerin temin edilmesi ve bu sistemlerin birbirleri ile entegrasyonuna yönelik modifikasyonların yapılması, özgün donanım ve yazılım geliştirme süreçlerinin tamamlanmasını kapsamaktadır. İncelenen parametreler: (1) Bina enerji üretim sistemleri ve kablosuz donanımların sorunsuz bir şekilde birlikte çalışabilmesi, (2) Sistem ve donanımlarda yapılacak modifikasyonlar sonrası oluşturulacak sistemlerin sorunsuz bir şekilde çalışabilmesi, (3) Bilgi işlem modülünün oluşturulması ve gösterdiği performans, (4) Bina enerji üretim sistemleri enerji performanslarının izlenmesi ve kullanıcı ara yüzlerinin uygunluğudur.

Projenin beşinci safhasında bina enerji üretim sistemleri arasındaki entegrasyon tamamlanmış, bu sistemler arasındaki optimizasyon ve senaryo bazlı algoritmalar tamamlanarak bütünleşik bir yapı teşkil edilmiştir. $\mathrm{Bu}$ iş paketinde yazılım, donanım ve sistem uyumları analiz edilmiştir. Geliştirilen yazılımların ve sistemlerin sorunsuz çalışmasına yönelik testler yapılmıştır.

Çalışmanın son sahasında, geliştirilen sistem konut ve kamu olmak üzere 2 farklı test binasına uygulanmıştır. Sistem hem laboratuvar ortamında kontrollü koşullar hem de gerçek kullanıcılar ile gerçek çevresel koşullar altında test edilmiştir. Test sonuçlarına göre iyileştirilmeleri tamamlanan prototip uygulamaları, patent/faydalı model başvruları ve ticarileştirme faaliyetleri için kullanılmıştır.

\section{Sistem Testleri}

Proje kapsamında sistemin geliştirme süreçlerinin yapılabilmesi, sistem entegrasyonu ve sonrasında sistem performansının ölçülebilmesi amacıyla kullanılacak 2 farklı test düzeneği teşkil edilmiştir. Birinci test düzeneği, İstanbul Teknik Üniversitesi Maslak Yerleşkeşi Arı Teknopark bünyesinde yer alan ar-ge laboratuvarlarımızda kontrollü çevresel koşullar oluşturarak özgün sistem geliştirme süreçlerinde kullanılma amaçlı kurulmuştur. İkinci test düzeneği Boğazköy / Başakşehir mevkiinde, 41,08 ve 28,66 koordinatlarında yer alan müstakil bir konutta kurgulanmıştır. Bu makalede ikinci test binası sistem kurgusu ve sonuçları paylaşılmıştır. Şekil 2'de seçilen test merkezinin konumu gösterilmektedir. Müstakil tipte bir konut seçilmesinin sebeplerinden biri fotovoltaik güneş paneli yerleşimi için yeterli çatı alanına ve enerji saklama sistemlerinin kurulabilmesi için uygun depolama olanaklarına sahip olan bir test merkezine ihtiyaç duyulmasıdır. Ayrıca rüzgar türbini ve direğinin yerleştirilmesi için de gerekli olan bahçe alanı seçilen test merkezinde mevcuttur. 


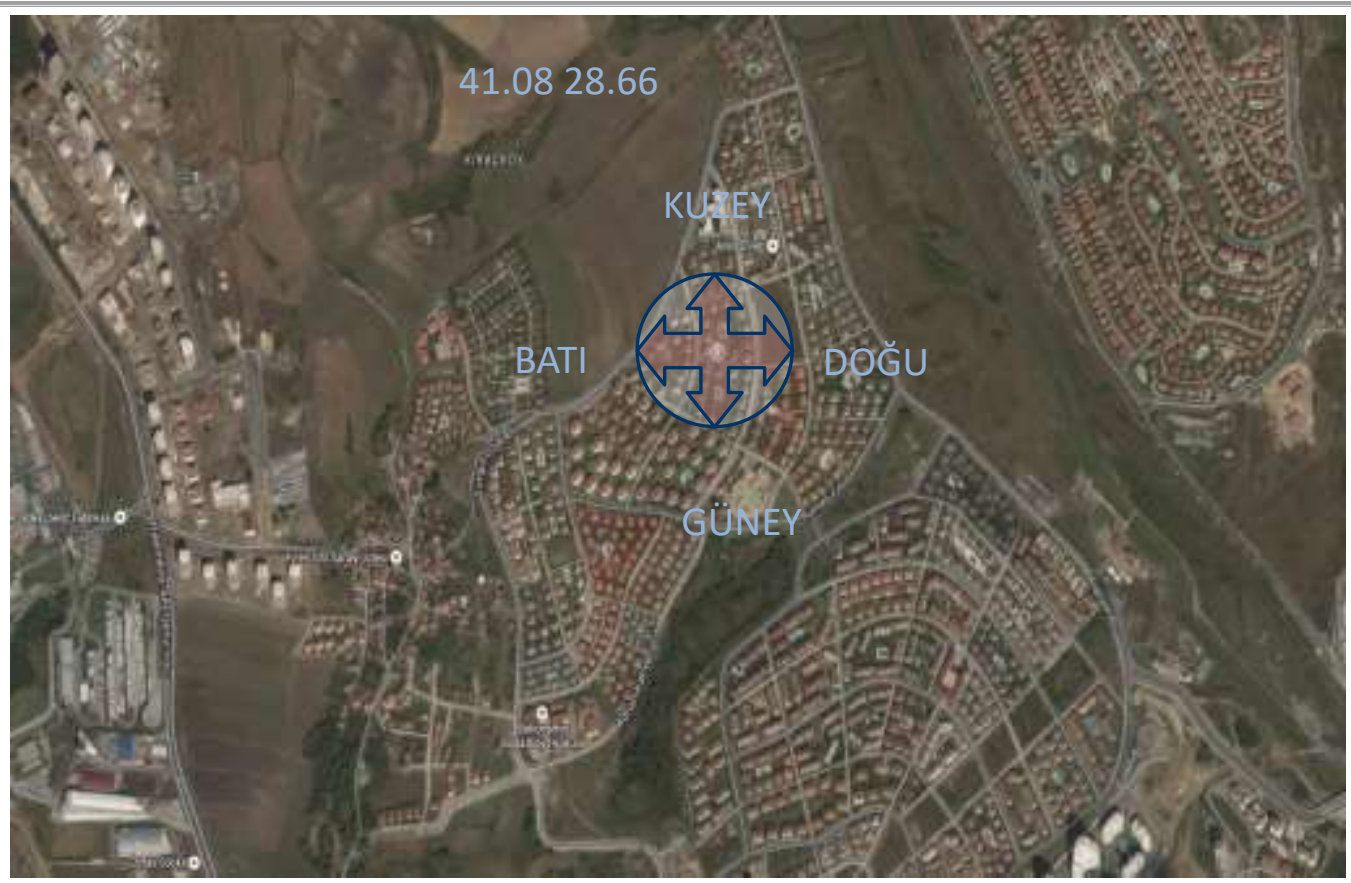

Şekil 2: Test Merkezi Uydu Görüntüsü

Test binasının seçiminin ardından, yapının teknik çizimleri Autodesk şirketine ait AutoCAD Ver. 21.0 bilgisayar destekli tasarım yazılımı kullanılarak modellenmiştir. Şekil 3 projede geliştirilen sistemlerin uygulandığı test binasının bilgisayar destekli teknik çizimlerini göstermektedir.

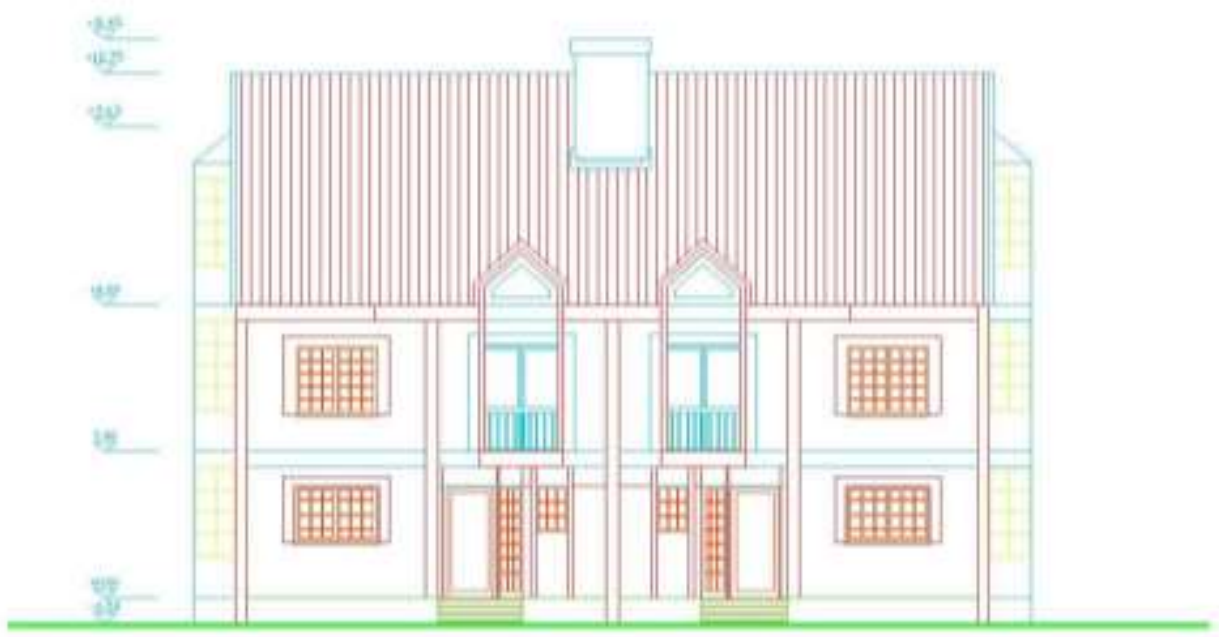

Şekil 3: Test Binası Teknik Çizimi (Önden Görünüşü) 
Gerçek çevresel ve kullanım koşullarına sahip test merkezinin, enerji ihtiyacı hesaplanırken binada bulunan ve Tablo 2'de verilen elektrikli ev aletlerinin 24 saatlik zaman diliminde tabloda belirtilen sürelerde çalıştı̆̆ tespit edilmiş ve çalışma güçlerine bağl1 olarak günlük ve yıllık toplam enerji ihtiyaçları belirlenmiştir.

Tablo 2: Test Merkezi Günlük ve Yıllık Toplam Enerji Tüketimi Tablosu.

\begin{tabular}{|c|c|c|c|c|c|c|}
\hline Adet & Adı & Markası & $\begin{array}{l}\text { Çalışma } \\
\text { Gücü } \\
\text { (W) }\end{array}$ & $\begin{array}{c}\text { Günlük } \\
\text { Kullanım } \\
\text { Süresi (saat) }\end{array}$ & $\begin{array}{l}\text { Günlük Enerji } \\
\text { Tüketimi } \\
\text { (kWh) }\end{array}$ & $\begin{array}{c}\text { Yıllık Enerji } \\
\text { Tüketimi } \\
\text { (kWh) }\end{array}$ \\
\hline 2 & Televizyon 55" & Samsung & 218 & 5 & 1,09 & 398 \\
\hline 1 & Elektrikli Fırın & Siemens & 990 & 1 & 0,99 & 361,5 \\
\hline 1 & Mikrodalga Fırın & Siemens & 1.270 & 0.5 & 0,635 & 232 \\
\hline 1 & Aspiratör & Siemens & 240 & 1 & 0,24 & 87,6 \\
\hline 1 & Bulaşık Makinası & Siemens & 2.400 & 1 & 2,4 & 1.752 \\
\hline 1 & Ütü & Siemens & 1.800 & 1 & 1,8 & 657 \\
\hline 1 & Elektrikli Süpürge & Siemens & 2.200 & 1 & 2,2 & 803 \\
\hline 1 & $5+1$ Ses Sistemi & Philips & 300 & 3 & 0,9 & 328,5 \\
\hline 2 & $\begin{array}{l}\text { Masaüstü } \\
\text { Bilgisayar }\end{array}$ & Dell & 300 & 3 & 0,9 & 328,5 \\
\hline 1 & Çamaşır Makinası & Siemens & 2.200 & 1 & 2,2 & 803 \\
\hline 1 & Klima & Siemens & 2.200 & 2 & 4,4 & 2.409 \\
\hline 1 & Su Isitıci & Philips & 2.400 & 0.5 & 1,2 & 438 \\
\hline 2 & $\begin{array}{l}\text { Bilgisayar Ekranı } \\
23 "\end{array}$ & Dell & 100 & 3 & 0,3 & 110 \\
\hline \multicolumn{5}{|c|}{ Toplam } & 19,625 & 7.026 \\
\hline
\end{tabular}

Tablo 2'de verilen ev aletlerinin kullanacağı güçler, ilgili aletlerin teknik spesifikasyonlarından alınmış olup, test merkezinde kullanılan modellere göre seçilmiştir. Günlük enerji tüketimi hesaplanırken çalışma gücü ile gün içinde çalışılacağ 1 öngörülen saat çarpılarak, kWh cinsinden ilgili cihazın günlük enerji tüketimi hesaplanmıştır.

Tablo 2'de de görüldügü üzere test binasında kullanılan elektrikli ev aletlerinin kullanımı sonucu günlük ortalama $19,625 \mathrm{kWh}$, yıllık ise $7.026 \mathrm{kWh}$ enerji gereksinimi bulunmaktadır.

Test merkezi olarak seçilen yapının iki adet 50 derece eğimli açıya sahip çatısı bulunmakta, bunlara ek olarak ise bir adet, yine panellerin yerleştirilebileceği çıkıntı çatısı bulunmaktadır. Yapının ön ve arka yüzleri doğu ve batıya bakmakta, çıkıntı olarak adlandırılan çatı kısmı ise güneye ve kuzeye bakmaktadır.

Geliştirilen sistem mimarisinde bina enerji tedarik katmanında bulunan fotovoltaik güneş paneli ve bina tipi rüzgar türbini yerleşimleri, gereklilik analizlerine ile teknik spesifikasyonlara uygun olarak bilgisayar ortamında üretim sistemi hesaplamaları yapılarak tasarlanmıştır.

Test merkezindeki çatı üzerinde en optimum güneş panelinin güney yüzüne bakacak şekilde konumlandırılması gerekirken, çatı alanındaki kısıtlamalar ve güvenlik sebeplerinden ötürü panel yerleşimleri görece kolay montaja sahip, düşük maliyetli ve güvenli olacak şekilde doğu ve bat1 yüzlerine dönük konumlandırılmıştır.

Bu konumlandırma biçimi enerji üretim verimliliği açısından optimum olmamasına rağmen, montaj maliyetlerini ve güvenlik riskini düşürmektedir. Güney yüzüne bakacak şekilde ise dört adet panel yerleştirilmiştir.

Proje kapsamında kullanılan güneş panelleri ve rüzgar türbini ile ilgili teknik spesifikasyonlar Şekil 4 ve Şekil 5'te verilmiştir. 


\begin{tabular}{|c|c|c|}
\hline & Nominal Güç Pmax (W) & $=235$ \\
\hline & Açik Devre Voltajı Voc (V) & $=37,15$ \\
\hline & Nominal Güç Voltajı Umpp (V) & $=30,20$ \\
\hline & Kisa Devre Akımı Isc (A) & $=8,43$ \\
\hline & Nominal Güç Akımı Impp (A) & $=7,79$ \\
\hline & "Günlük Öngörülen Elektrik Öretimi (kWh) & $=\sim 0,7 \cdot 1,4$ \\
\hline & Panel Boyutlan & $=1,663 \mathrm{~m} \times 0,998 \mathrm{~m}$ \\
\hline & Panel Alanı & $=1,66 \mathrm{~m}^{2}$ \\
\hline & Panel Verimliligi & $=15 \%$ \\
\hline
\end{tabular}

"Yaz aylan baz alinarak

Şekil 4: Fotovoltaik Güneş Paneli Spesifikasyonları
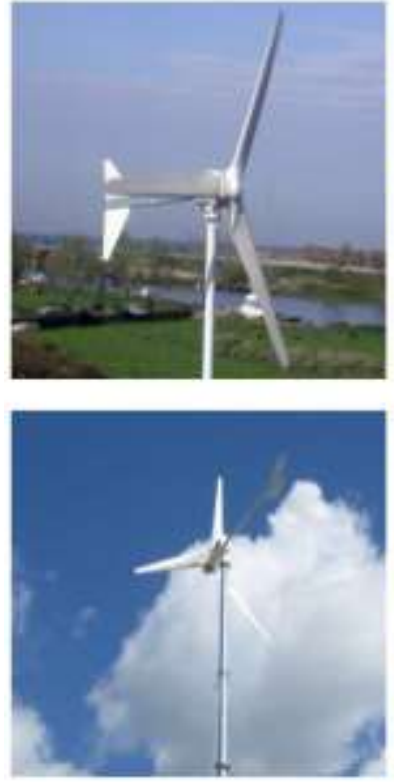

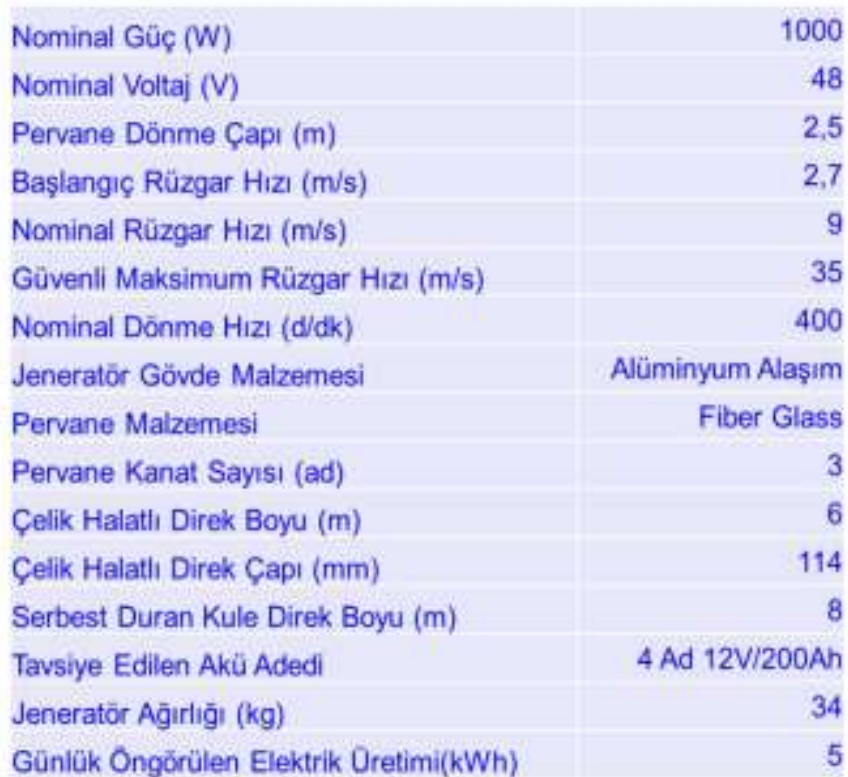

Şekil 5: Rüzgar Türbini Spesifikasyonları

Sistemde Abax-Hybrid marka evirici (Şekil 6) fotovoltaik güneş panellerine bağlanmıştır. Şebekeye bağlı olarak ve/veya şebeke dışı çalışma ve pillerin şarj kontrollünün yapılması fonksiyonları, üzerindeki hâlihazırda gelen yazılım ve kullanıcı arayüzü ile yapılmaktadır. Fakat evirici tarafından yapılan ölçüm verilerini eviricinin arayüzü üzerinden çekmek mümkün olmadığı için bu eviriciye ek olarak özgün geliştirilen donanımlara ve EOS arayüz yazılımına uygun olan, kablosuz ağlı gömülü teknolojileri içeren yeni bir elektronik devre kartı tasarımı da yapılarak bu sisteme entegre edilmiştir. 


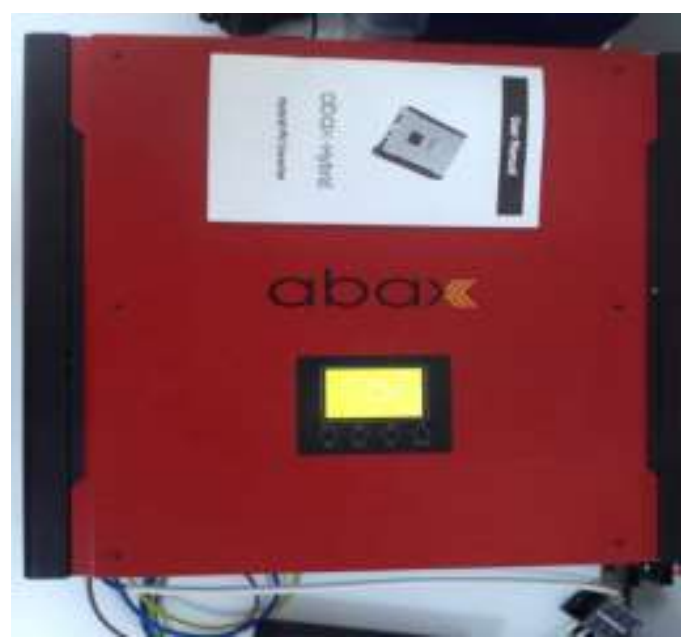

Şekil 6: Kullanılan Abax-Hybrid Marka Evirici

Fotovoltik güneş panellerinden yapılabilecek enerji üretimi hesaplamaları ve sistem testlerinin doğruluğunun kontrol edilmesi için Avrupa Birliği Enerji ve Ulaştırma Enstitüsüne ait "Photovoltaic Geographical Information System (PVGIS)" programı kullanılmıştır. Program grafiksel kullanıcı arayüzü Şekil 7'de gösterilmiştir.

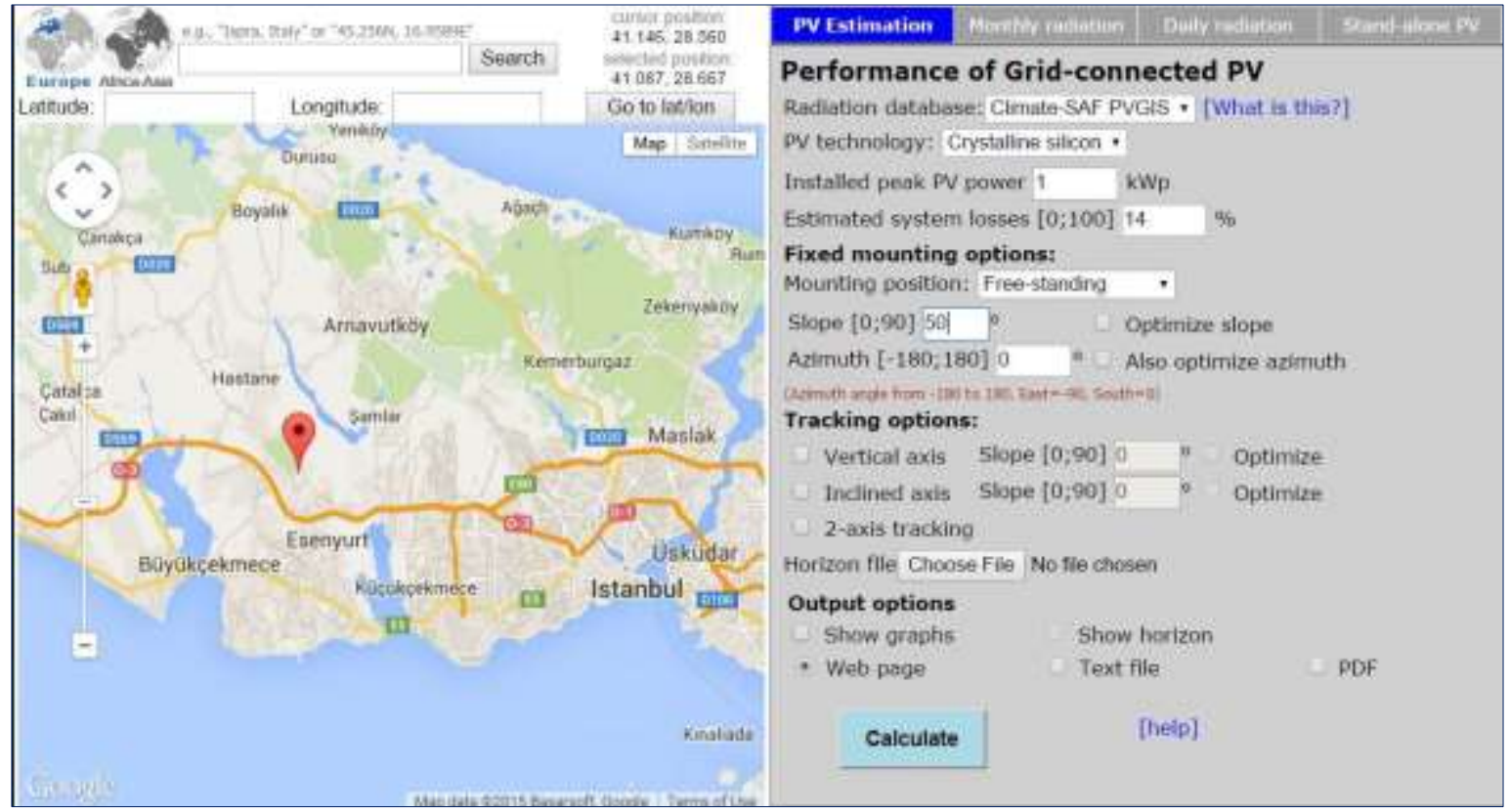

Şekil 7: Photovoltaic Geographical Information System (PVGIS) Programı.

Işıma değerlerini de içerecek şekilde programdan elde edilen sonuçlar ve test merkezinin gereklilikleri hesaplanarak test binasına 20 adet fotovoltaik güneş paneli yerleştirilmesi uygun bulunmuştır. Panel montajları Şekil 8'de görüldüğü gibi tamamlanmıştır. 


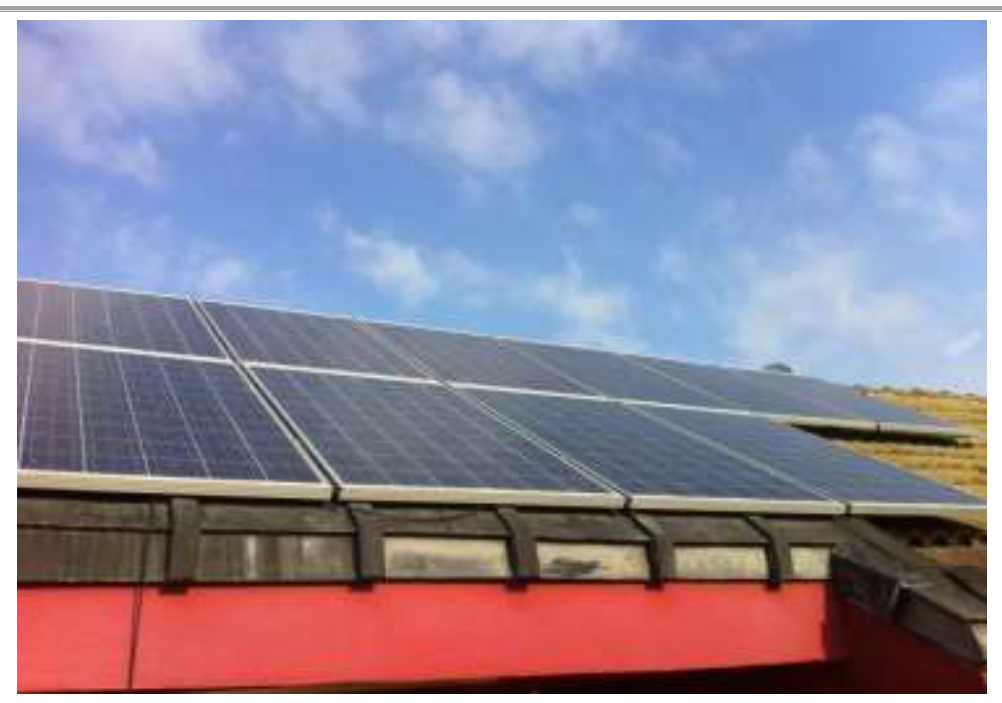

Şekil 8: Montajı Tamamlanmış Fotovoltaik Güneş Panelleri.

Kullanılmakta olan güneş panelleri optimum koşullarda \%14 çalışma verimliliğine sahip olup, her biri 1,66 $\mathrm{m}^{2}$ alan kaplamaktadır. Montajı tamamlanmış ve sisteme bağlanmış olan 20 adet güneş panelinden, ölçümler sonucu yıl içi gün ortalaması olarak, test merkezinin konumu, sistem kayıpları ve panel sıcaklığı gibi faktörler de göz önüne alınmak sureti ile toplamda yaklaşık olarak $14 \mathrm{kWh}$ enerji üretildiği tespit edilmiştir. Panellerin yerleştirilme düzeni, 8 adet doğu, 8 adet batı, 4 adet ise güney yüzüne bakacak şekilde yapılmıştır. Bu yerleşim düzenine göre elde edilen enerji miktarları Tablo 3'de verilmiştir.

Tablo 3: Fotovolataik Güneş Panelleri Yerleşim Düzeni ve Hesaplanan Enerji Üretimi.

\begin{tabular}{cccccc}
\hline $\begin{array}{c}\text { Güneş Paneli } \\
\text { Gücü }(\mathbf{W p})\end{array}$ & $\begin{array}{c}\text { Ade } \\
\mathbf{t}\end{array}$ & $\begin{array}{c}\text { Kurulu } \\
\text { Güç }(\mathbf{W p})\end{array}$ & $\begin{array}{c}\text { Panel } \\
\text { Oryantasyonu }\end{array}$ & $\begin{array}{c}\text { Yıl içi günlük } \\
\text { Ortalama Enerji } \\
\text { Üretimi (kWh) }\end{array}$ & $\begin{array}{c}\text { Yıllık Enerji } \\
\text { Üretimi (kWh) }\end{array}$ \\
\hline 235 & 8 & 1.880 & Batı & 5,18 & 1.890 \\
235 & 8 & 1.880 & Doğu & 5,26 & 1.920 \\
235 & 4 & 940 & Güney & 3,37 & 1.230 \\
Toplam & $\mathbf{2 0}$ & $\mathbf{4 . 7 0 0}$ & & $\mathbf{1 3 , 8 1}$ & $\mathbf{5 . 0 4 0}$ \\
\hline
\end{tabular}

Enerji ölçümleri bu proje kapsamında özgün olarak geliştirilmiş sayaç fonksiyonuna sahip sensörler vasıtası ile yapılmış ve doğruluğu PVGIS programı ile teyit edilmiştir. Ayrıca buna ilave olarak "işıma değerlerine" göre hesaplamalar yapılıp, sensör değerleri ve AB Enerji ve Ulaşım Komisyonu hesaplama değerleri ile sağlaması yapılmıştır. Hesaplamalar yapılırken doğru, yaygın ve yansıma 1şımaları göz önüne alınmış, meydana gelebilecek olası sistem kayıpları ise elde edilecek enerjiden düşülmüştür. Tablo 3' de verildiği üzere yirmi adet panelden y1l içi gün ortalaması olarak yaklaşık olarak $14 \mathrm{kWh}$ enerji üretildiği tespit edilmiştir.

Tablo 4 ve Tablo 5'de yaz ve kış ayları için ortalama günlük enerji üretimi kWh cinsinden verilmiştir. Tablo 4' te de görüldügü üzere yaz aylarında paneller test merkezinin elektrik enerjisi gereksinimi karşılayabilmekte, Tablo 5' te görüldügüu üzere ise kış aylarında güneş enerjisinden evin ihtiyacı olan elektrik enerjisi tamamen karşılanamamakta, kalan enerjinin rüzgar enerjisinden ve şebekeden sağlanması gerekmektedir. 
Tablo 4: Yaz Ayları Günlük Enerji Üretimi Ortalaması (Mayıs - Ağustos Ayları).

\begin{tabular}{ccccc}
\hline $\begin{array}{c}\text { Panel Nominal Güç } \\
(\mathbf{W p})\end{array}$ & Adet & $\begin{array}{c}\text { Kurulu Güç } \\
(\mathbf{W p})\end{array}$ & $\begin{array}{c}\text { Panel } \\
\text { Oryantasyonu }\end{array}$ & $\begin{array}{c}\text { Yıl içi günlük Ortalama Enerji } \\
\text { Üretimi (kWh) }\end{array}$ \\
\hline 235 & 8 & 1.880 & Bat1 & 8,06 \\
235 & 8 & 1.880 & Doğu & 8,20 \\
235 & 4 & 940 & Güney & 4,35 \\
Toplam & 20 & 4.700 & & 20,74 \\
\hline
\end{tabular}

Tablo 5: Kış Ayları Günlük Enerji Üretimi Ortalaması (Eylül - Nisan Ayları).

\begin{tabular}{ccccc}
\hline $\begin{array}{c}\text { Panel Nominal Güçç } \\
(\mathbf{W})\end{array}$ & Adet & $\begin{array}{c}\text { Kurulu Güç } \\
(\mathbf{W})\end{array}$ & $\begin{array}{c}\text { Panel } \\
\text { Oryantasyonu }\end{array}$ & $\begin{array}{c}\text { Yll içi günlük Ortalama Enerji } \\
\text { Üretimi (kWh) }\end{array}$ \\
\hline 235 & 8 & 1.880 & Batı & 2,2 \\
235 & 8 & 1.880 & Doğu & 2,3 \\
235 & 4 & 940 & Güney & 2 \\
Toplam & 20 & 4.700 & & 6,5 \\
\hline
\end{tabular}

Tablo 3'te de belirtildiği üzere yaz ayları üretilecek olan günlük ortalama enerji $20,74 \mathrm{kWh}$ olup, evin ihtiyacı olan 19,25 kWh enerjiyi karşılamakta ve yaklaşık olarak günde ortalama 1,5 kWh'de fazla enerji üretimi gerçekleştirerek şebekeye geri verilebilmektedir.

Kış aylarında ise evin ihtiyacı olan enerji miktarının günde yalnızca \%34'ü güneş panellerinden karşılanmakta, geri kalan enerji ihtiyacının ise rüzgar enerjisinden ve şebekeden sağlanması gerekmektedir. Mevcut yirmi adet güneş paneli ile yılın 4 ayı ihtiyaçtan fazla enerji elde edilebilmekte, proje amaçlarından biri olan binadan üretilen yenilenebilir elektrik enerjisinin şebekeye geri verilmesi (satışı) ile sıfir emisyonlu enerji üretim ve optimizasyonu bu aylarda olası hale gelmektedir. Yılın kalan kısmında ise test binansının enerji ihtiyacının büyük bir bölümü yalnızca fotovoltaik güneş panellerinden karşılanabilmektedir. Yapılan ölçümlere göre Mayıs Ağustos ayları toplamında 139,2 kWh fazla enerji üretilerek ve şebekeye verilmiştir.

Oluşturulan bütünleşik sistemin binanın bütün enerjsini karşılaması ve yenilenebilir kaynaklardan üretilen sıfır emisyonlu fazla enerjinin şebekeye verilebilmesi ile oluşturulacak enerji plus bina oluşturulması amacıyla fotovoltaik güneş panellerine ek olarak spesifikasyonları önceki bölümlerde verilen rüzgar türbini teşkil edilmiş ve test merkezinin bahçesine 12 metre yüksekliğinde özel üretilmiş galvaniz kaplamaya sahip çelik direk üzerine montajı tamamlanmıştır (Şekil 9).

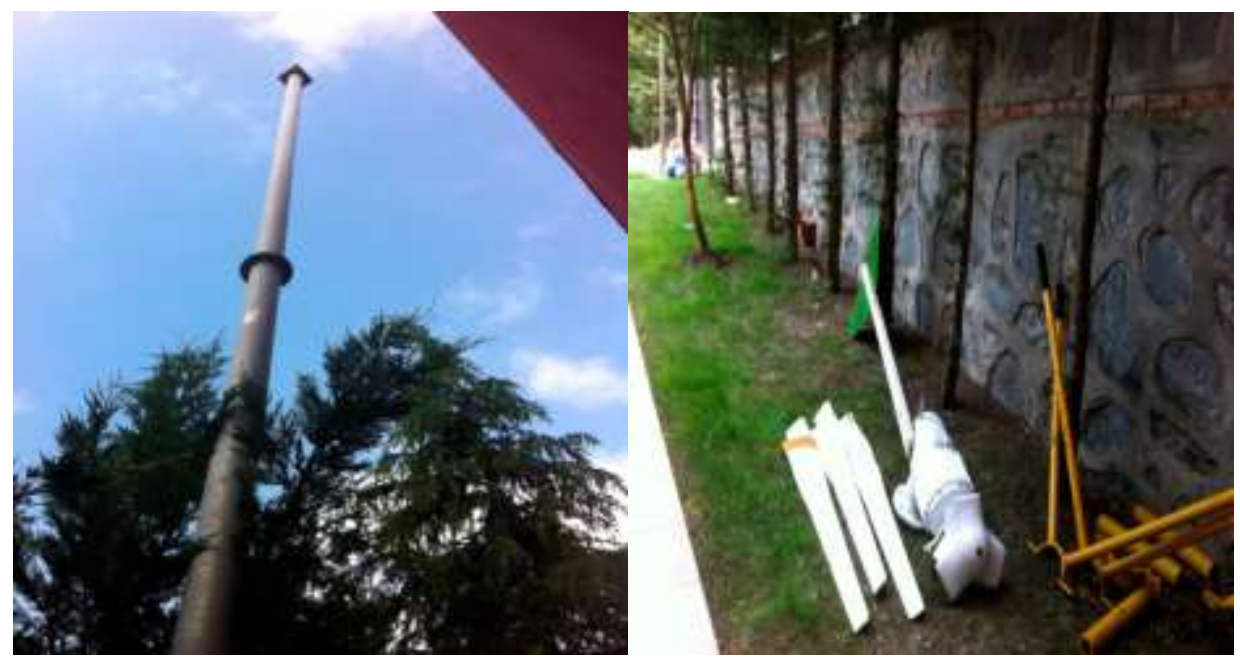

Şekil 9: Rüzgar Türbini Montaj Aşamaları. 
Tablo 11'de test merkezinde geliştirilen sensörler kullanılarak ölçülen rüzgar hızına bağlı olarak rüzgar türbininden elde edilen günlük ve yıllık ortalama enerji üretim değerleri verilmiştir.

Tablo 11: Kış Ayları Günlük Enerji Üretimi Ortalaması.

\begin{tabular}{cccccc}
\hline $\begin{array}{c}\text { Nominal } \\
\begin{array}{c}\text { Güç } \\
\text { (Wp) }\end{array}\end{array}$ & Adet & $\begin{array}{c}\text { Kurulu } \\
\text { Güç } \\
(\mathbf{W p})\end{array}$ & Yerleşim & $\begin{array}{c}\text { Rüzgar Hızna Bağlı günlük } \\
\text { Ortalama Enerji Üretimi } \\
(\mathbf{k W h})\end{array}$ & $\begin{array}{c}\text { Yıllık Enerji } \\
\text { Üretimi } \\
(\mathbf{k W h})\end{array}$ \\
\hline 1000 & 1 & 1.000 & $\begin{array}{c}12 \mathrm{~m} \text { direk üzerinde } \\
\text { test merkezi bahçesi }\end{array}$ & $3,6 \mathrm{kwh}$ & 1.314 \\
Toplam & 1 & 1.000 & & $3,6 \mathrm{kwh}$ & 1.314 \\
\hline
\end{tabular}

Sistemin bağlantıları, test binası bahçesinde inşa edilen kontrol odası içinde bulunan ağır yük tipi raflarda 12 adet 10,8 V 90 Ah değerlerine sahip Yuasa SWL 2500T kurşun asit akülerden oluşan enerji saklama modülü ve ABAX marka evirici'nin bağlanması ile tamamlanmıştır (Şekil 10).
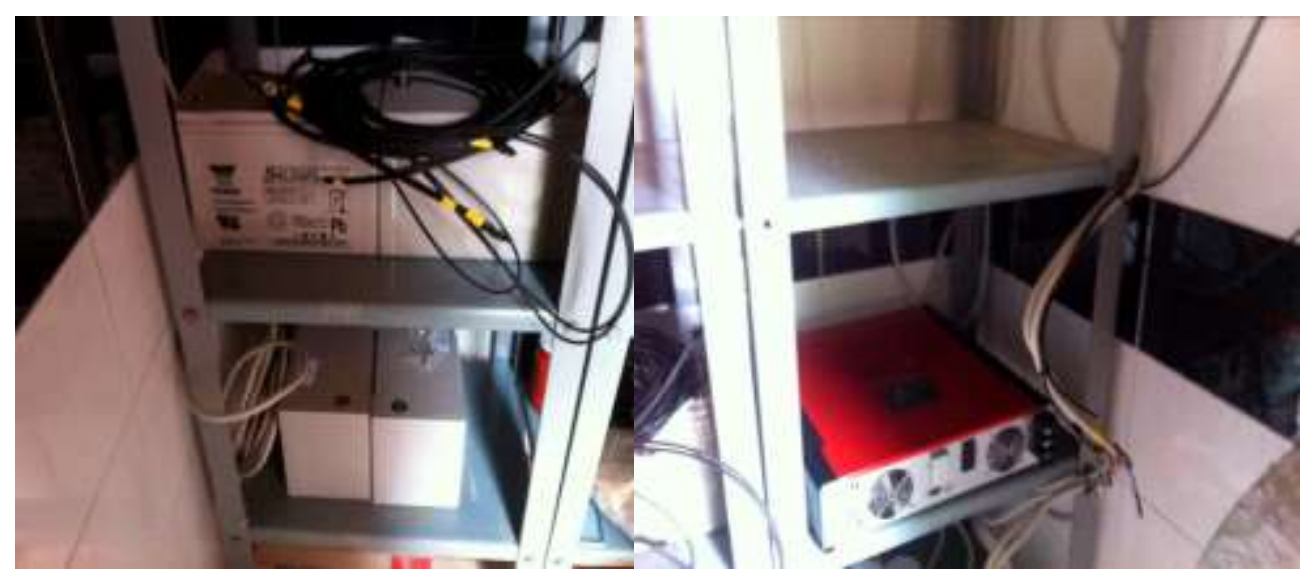

Şekil 10: Akü Kümesi ve Eviricinin Test Merkezinde Kurulumu.

Yapılan ölçümlerede özellikle kış aylarında 1şımanın ve rüzgar hızının düşük olduğu zaman dilimlerinde güneş ve rüzgar'dan elde edilen enerjinin test binasının ihtiyacı olan enerjiyi karşılayamadığ belirlenmiştir. Tablo 12 'de kış aylarında güneş ve rüzgar'dan elde edilen enerji miktarları verilmiştir.

Tablo 12: Kış Ayları Günlük Rüzgar ve Güneş Enerji Üretimi Ortalaması.

\begin{tabular}{lcccc}
\hline $\begin{array}{c}\text { Panel Nominal } \\
\text { Güç (Wp) }\end{array}$ & Adet & $\begin{array}{c}\text { Kurulu } \\
\text { Güç } \\
(\mathbf{W p})\end{array}$ & Yerleşim & $\begin{array}{c}\text { Yıl içi günlük Ortalama } \\
\text { Enerji Üretimi (kWh) }\end{array}$ \\
\hline 235 (Güneş Paneli) & 8 & 1.880 & Batı Cephe & 2,2 \\
235 (Güneş Paneli) & 8 & 1.880 & Doğu Cephe & 2,3 \\
235 (Güneş Paneli) & 4 & 940 & Güney Cephe & 2 \\
1000 (Rüzgar & 1 & 1.000 & $\begin{array}{c}\text { 12 m direk üzerinde test } \\
\text { merkezi bahçesi }\end{array}$ & 3,6 \\
Türbini) & & Toplam & & $\mathbf{1 0 , 1}$ \\
\hline
\end{tabular}

$\mathrm{Bu}$ verilere göre kış ayları test merkezi günlük kullanımı için gerekli olan 9.525 Kilowatt saatlik miktarın, şebekeden ve/veya diğer yenilenebilir enerji kaynaklarından, (örnek olarak 1sı pompası ve hidrojen yakıt hücreleri) karşılanması gereklidir. Makalenin yazarlarının, 1S1 pompası ve hidrojen yakıt hücrelerinin sisteme entegrasyonu ile ilgili çalışmaları devam etmektedir. Diğer bir alternatif ise rüzgar türbini nominal gücünün ve adedinin arttırılmasıdır. Fakat bu çözüm oluşturucağı ses nedeniyle rahatsızlık yaratabileceği için şehir içinde bulunan binalarda kullanılması uygun değildir. 


\section{EOS Donanım ve Yazılımları}

$\mathrm{Bu}$ proje kapsamında özgün olarak tasarlanarak geliştirilen kablosuz ağlı gömülü teknolojilere sahip donanımlar ve gömülü yazılımlarının test merkezindeki kullanım metodları aşağıdaki tabloda özetlenmiştir (Tablo 12).

Tablo 12: Geliştirilen Donanımların Test Merkezinde Uygulanması.

\begin{tabular}{|c|c|c|c|c|}
\hline No & $\begin{array}{c}\text { Donanım ve } \\
\text { Yazılım }\end{array}$ & Tanım & Kullanım Yeri & Kullanım Amacı \\
\hline 1 & EOS Algılayıcı & $\begin{array}{l}\text { Isı, 1şıma, nem, } \\
\text { rüzgar hızı } \\
\text { seviyelerinin } \\
\text { gerçek zamanlı } \\
\text { olarak ölçülmesi } \\
\text { için kullanılır. }\end{array}$ & $\begin{array}{l}\text { Test Merkezi } \\
\text { Çatısı - Güneş } \\
\text { panellerine } \\
\text { entegre edilmiştir. } \\
\text { Rüzgar türbini - } \\
\text { Rüzgar türbinine } \\
\text { entegre edilmiştir. }\end{array}$ & $\begin{array}{l}\text { Güneş ve rüzgardan elde } \\
\text { edilebilecek enerji miktarlarının } \\
\text { analiz ve tahmin edilmesi amacıyla } \\
\text { oluşturulan algortimalara veri } \\
\text { sağlamaktadır. }\end{array}$ \\
\hline 2 & $\begin{array}{l}\text { EOS Aç-Kapa } \\
\text { Kontrolörü }\end{array}$ & $\begin{array}{l}\text { Binaya entegre } \\
\text { edilen tüm enerji } \\
\text { üreten sistemlerin } \\
\text { aç-kapa } \\
\text { fonksiyonlarını } \\
\text { optimize eder. }\end{array}$ & $\begin{array}{l}\text { Enerji Saklama } \\
\text { Modülü - Şarj } \\
\text { giriş ve enerji } \\
\text { çıkış bağlantı } \\
\text { noktaları. } \\
\text { Şebeke giriş } \\
\text { bağlantı noktası. } \\
\text { Evirici - Bina } \\
\text { bağlantı noktaları. }\end{array}$ & $\begin{array}{l}\text { Güneş ve rüzgardan elde edilen } \\
\text { enerji değerleri ve bina enerji } \\
\text { kullanım yoğunluğuna göre } \\
\text { geliştirilen optimizasyon yazılımı } \\
\text { tarafından verilen kararlar } \\
\text { doğrultusunda enerji saklama } \\
\text { modülü şarjı, şebekenden enerji } \\
\text { kullanımı ve enerji tedariği karar } \\
\text { süreçlerinin optimize edilmesi } \\
\text { amacıyla kullanılmıştır. }\end{array}$ \\
\hline 3 & EOS Sayaç & $\begin{array}{l}\text { Elektrik } \\
\text { üretiminin ve } \\
\text { sarfiyatının } \\
\text { gerçek zamanlı } \\
\text { ölçülmesi için } \\
\text { kullanılır. }\end{array}$ & $\begin{array}{l}\text { İnvertör bağlantı } \\
\text { noktaları. } \\
\text { Enerji Saklama } \\
\text { Modülü şarj giriş } \\
\text { bağlantı noktaları. }\end{array}$ & $\begin{array}{l}\text { Enerji üretim ve kullanım } \\
\text { miktarlarının anlık olarak ölçülmesi } \\
\text { amacıyla kullanılmıştır. }\end{array}$ \\
\hline 4 & $\begin{array}{l}\text { EOS Kelepçeli } \\
\text { Sayaç }\end{array}$ & $\begin{array}{l}\text { İstenilen alanın ve } \\
\text { sistemin elektrik } \\
\text { sarfiyatının } \\
\text { gerçek zamanlı } \\
\text { ölçülmesi için } \\
\text { kullanılır. }\end{array}$ & $\begin{array}{l}\text { Güneş Panelleri } \\
\text { enerji çıkış } \\
\text { noktaları. } \\
\text { Rüzgar Tribünü } \\
\text { enerji çıkış } \\
\text { noktaları. }\end{array}$ & $\begin{array}{l}\text { İstenilen sistemin ve alanın elektrik } \\
\text { sarfiyatının gerçek zamanlı } \\
\text { ölçülmesi için kullanılır. Rüzgar } \\
\text { türbini, güneş panelleri ve şebeke } \\
\text { ana akım kablolarına kelepçeli sayaç } \\
\text { vasıtası ile bağlanılır. }\end{array}$ \\
\hline 5 & $\begin{array}{l}\text { EOS Sinyal Ağı } \\
\text { Yönlendiricisi }\end{array}$ & $\begin{array}{l}\text { Sistemde } \\
\text { kullanılan } \\
\text { algılayııı ve } \\
\text { kontrol } \\
\text { ünitelerinin birbiri } \\
\text { ile kablosuz } \\
\text { haberleşmesini } \\
\text { sağlar. }\end{array}$ & $\begin{array}{l}\text { Test merkezi } \\
\text { kontrol binasında } \\
\text { yer almaktadır. }\end{array}$ & $\begin{array}{l}\text { Sisteme entegre edilen kablosuz } \\
\text { algılayıcı ve kontrol ünitelerinden } \\
\text { toplanan verilerin ana işlemci } \\
\text { ünitesine içinde yürütülen EOS } \\
\text { yazılımına kablosuz olarak } \\
\text { aktarılması amacıyla kullanılmıştır. }\end{array}$ \\
\hline
\end{tabular}




\section{Tartışma}

Bu çalışmada "TÜBİTAK Teydeb 1507 KOBİ Ar-Ge Başlangıç Destek Programı çerçevesinde yürütülmüş olan 7130241 proje numaralı "Binalardan Enerji Üretilmesi ve Akı1lı Enerji Yönetimi için Bütünleşik Sistem Mimarisinin Geliştirilmesi" projesi ve proje çıktıları sunulmuştur. Proje kapsamında yenilenebilir enerji sistemleri kullanılarak binalardan sifır emisyonlu enerji üretilmesi ve bu enerjinin verimli kullanımına yönelik enerji entegrasyon ve optimizasyon sistemi Ar-Ge süreçleri ile birlikte ele alınmıștır. İstanbul Teknik Üniversitesi Arı Tekonokent bünyesinde yer alan EOS A.Ș. firmasına ait laboratuvar ortamında ve İstanbul ili sınırlarında yer alan müstakil bir binada test edilerek elde edilen üretim/verimlilik değerleri hem laboratuvar şartlarında hem de gerçek kullanıcılar ile gerçek çevresel koşullar altında test edilmiştir.

Test edilen sistemde güneş panelleri ve rüzgar türbininden enerji üretimi, elde edilen enerjinin bataryalarda saklanması, konut ihtiyacı için kullanılması ve fazla enerjinin şebekeye verilmesi için gerekli olan parametreler ele alınmıştır. Test yeri olan İstanbul ili, yazları sıcak ve kurak, kışları 1lık ve yağışlı olan Akdeniz ikliminden yazları sıcak ve kışları 1lık ama her mevsim yağışlı Karadeniz iklimine geçişin gerçekleştiği bir bölgede yer alır (İ̈DEP, 2020). İstanbul'un coğrafik konumu, yapılan testlerin sistemin farklı iklim koşullarında test edilebilmesi avantajını da beraberinde getirmiştir.

Sistem testleri, bu proje kapsamında geliştirilen EOS Bütünleşik Bina Enerji Üretimi Sisteminin farklı iklim koşullarında dahi gerekli olan maksimum enerji değerlerinin optimizasyonunu sağlayacabilecek bir performans ortaya koyduğunu göstermiştir.

Yaz aylarında elde edilen fazla enerjinin şebekeye verilmesi/satılması ile ilgili son kullanıcı için elde edilecek faydalar güncel enerji fiyatları temelinde yatırım geri dönüş süresinin görece kısa bir dönemde karşılanabileceğini ortaya koymaktadır.

$\mathrm{Bu}$ sistemin farklı bina tiplerinde uygulanması ile bina sahiplerinin yararlanabileceği ekonomik faydanın yanı sıra, elde edilebilecek enerji üretim değerleri ile karbon emisyonlarının da önemli ölçüde düşürülebileceği görülmüştür. İncelenen tüm kategorilerdeki faydalar birbiriyle ilişkilidir, bu da binalardan enerji üretimi sonucu elde edilebilecek farklı ve çoklu faydaların bütün spektrumu kapsayacak şekilde analiz edilmesini gerektirir.

Türkiye ve Avrupa Ülkeleri, vatandaşlarına binalardan enerji üretimi ve enerji verimliliğinin önemine yönelik farklı tanıtım kampanyaları sunmalarına rağmen, tüm avantajları gösteren ve son kullanıcıları yönlendiren bütüncül bir yaklaşımı ortaya koyamamaktadırlar. Bu şekilde eksik kurgulanmış yaklaşımlar, EOS Bütünleşik Bina Enerji Üretimi Sistemi ve buna benzer sistemlerin ülkeler bazında yaygınlaşmasını da engelleyerek, Kyoto, Kopenhag ve en son olarak Paris iklim zirvesinde kararlaştırılmış olan enerji verimlilik ve karbon emisyon hedeflerine de ulaşmayı imkânsız hale getirmektedir.

Bu noktada mevcutta hızlanarak artan çevresel problemlere yönelik, karar mercilerinin tanıtım ve yönlendirmeleri haricinde, enerji üretim ve verimlilik sistemlerinin kesin kurallarla ve kanunlarla uygulanabilir olması önemlidir. Daha fazla bina ve konut sahibi, daha iyi enerji yönetimi ile gerçekleşecek farklı ve çoklu faydaları ne kadar çok tanıyabilir ve yatırımlarını bu doğrultuda gerçekleştirebilirse, ülkelerin uzun vadeli enerji politikası hedeflerine ulaşmaları o ölçüde kolay olacaktır.

Bunların 1şığında, Ar\&Ge projesinin ve geliştirilen sistemin son kullanıcıya, ülkeye ve çevreye sağlayacağ çoklu fayların irdelenerek proje sonuçlarının farklı açılardan değerlendirilmesi amacı ile yapılacak bir tekno-ekonomik analiz çalışması faydalı ve tamamlayıcı olacaktır.

Ayrıca, kış aylarındaki üretim ve tüketim miktarıları temelinde, mevcut enerji ihtiyacının karşılanmasına yönelik diğer enerji üreten parametrelerin ve yenilenebilir enerji sistemlerinin de 
devreye alınması örnek olarak; 1sı pompaları, yakıt hücre teknolojileri, EOS Enerji Optimizasyon Sistemi vb. gibi, binaların enerji noktasında kendi kendine yetebilmelerini de sağlayacaktır.

\section{Sonuç}

$\mathrm{Bu}$ makalede, TÜBİTAK Teydeb 1507 KOBİ Ar-Ge Başlangıç Destek Programı çerçevesinde İstanbul Teknik Üniversitesi Arı Tekonokent bünyesinde yer alan EOS A.Ş. firması tarafından yürütülmüş olan "Binalardan Enerji Üretilmesi ve Akıllı Enerji Yönetimi için Bütünleşik Sistem Mimarisinin Geliştirilmesi" projesi kapsamında binalardan enerji üretilmesine ve enerji verimliliğine yönelik, entegre yapılar, bütünleşik izleme ve analiz metodları, sürdürülebilir yönetim ve karar destek sistemlerini içeren temel araştırma faaliyetleri içerisinde bulunulmuş, binalarda kullanılacak bina enerji üretim sistemlerinin optimum bir şekilde entegrasyonu ile elde edilen EOS Bütünleşik Bina Enerji Üretim Sistemi ve sistem bileşenleri detaylı bir şekilde açıklanmıştır.

EOS Bütünleşik Bina Enerji Üretimi Sistemi Şebekeden Bağımsız Bina Enerji Üretim ve Saklama Sistemleri, Kablosuz Algılayıcı Katmanı, Bilgi İşlem Modülü, İzleme aracı, Akı1lı Kontrol ve Optimizasyon Aracı gibi farklı ve birbirleri ile entegre çalışan teknolojileri içermektedir.

Geliştirilen sistem proje sahibi firmaya ait ofis ve ait laboratuvar ortamında ve İstanbul ili sınırlarında yer alan müstakil bir binada uygulanarak elde edilen üretim/verimlilik değerleri hem laboratuvar şartlarında hem de gerçek kullanıcılar ile gerçek çevresel koşullar altında test edilmiştir. Geliştirilen sistem kablosuz donanımlar ve senaryo tabanlı algoritmalardan oluşan yazılım yardımı ile binalardan enerji üretimini destekleyen sistemleri izleyerek ve optimize ederek binaların toplam enerji kullanımını maliyet etkin bir şekilde düşürmektedir.

EOS eski, yeni ve farklı kulanım amaçlarına sahip binalarda uygulanabilmektedir. Yapılan testler sonucunda geliştirilen sistemin farklı mevsimsel koşullar altında en düşük $10,1 \mathrm{kWh}$ ile en yüksek 24,36 kWh aralığında enerji üretimi sağladığı kayıt altına alınmıştır.

\section{Teşekkür Bölümü}

$\mathrm{Bu}$ makalede irdelenen çalışma, Türkiye Bilimsel ve Teknolojik Araştırma Kurumu (TÜBİTAK) Teknoloji ve Yenilik Destek Programları Başkanlığı (Teydeb) KOBİ Ar-Ge Başlangıç Destek Programı kapsamında, EOS İstanbul Sürdürülebilir Enerji Çözümleri A.Ş. firması tarafından yürütülmüss olan 7130241 proje numaralı "Binalardan Enerji Üretilmesi ve Akıllı Enerji Yönetimi için Bütünleşik Sistem Mimarisinin Geliştirilmesi Projesi” çıktılarıdır.

Bu projede Proje Yöneticisi ve Ar\&Ge Yöneticisi olarak görev alan makalenin yazarları, başta TÜBİTAK olmak üzere projede görev alan ve desteklerini esirgemeyen tüm paydaşlara teşekkürlerini sunar.

\section{Kaynakça}

Abhishiktha, Ratna, Dipankur, V. Indraja, \& V. Hari (2016). A review on small scale wind turbines. Renewable and Sustainable Energy Reviews, Volume 56, 2016, Pages 1351-1371, ISSN 1364-0321, https://doi.org/10.1016/j.rser.2015.12.027. Erişim Adresi: http://www.sciencedirect.com/science/article/pii/S1364032115014100

Bogdan A., Chantal D., Marina E., Joana M., Ingeborg N. \& Oliver R. (2011). Europe's buildings under the microscope, A country-by-country review of the energy performance of buildings. Buildings Performance Institute Europe (BPIE), 2011.

BOTAS (2017).
https://www.botas.gov.tr/uploads/galeri/5c6ded9d4cd5f20.02.2019sektorap_2016.pdf

BOTAS (2019). BOTAS Sektör Raporu. Erişim Adresi:


https://www.botas.gov.tr/uploads/galeri/844491-2018sektorraporu.pdf, Erişim Tarihi: 10.11.2020.

Buildwise (2009). Buildwise Projet: Building A Sustainable Future. Erişim Adresi: http://www.iruse.ie/iruse/projects/-finishedprojects-/buildwise/. Erişim Tarihi: 10.06.2020.

COP 23 (2017). COP23: UN Climate Change Conference 2017 Erişim Adresi: https://unfccc.int/resource/docs/2017/cop23/eng/113.pdf Erişim Tarihi: 02.12.2020.

Dünya Bankası (2020b). World Bank. Erişim Adresi: https://data.worldbank.org/indicator/NY.GDP.MKTP.CD?locations=TR, Erişim Tarihi: 10.09.2020.

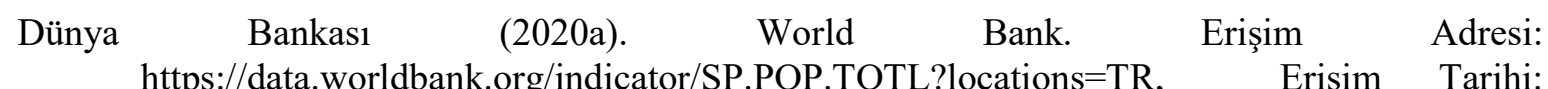
10.11./data.worldbank.org/indicator/SP.POP.TOTL?ocations=TR, Erişim Tarihi: 10.11.2020.

Dünya Bankası (2020c). World Bank. Erişim Adresi: https://data.worldbank.org/indicator/EN.ATM.CO2E.PC?end=2014\&locations=TR\&start= 1980, Erişim Tarihi: 10.11.2020.

EC (2011). European Comission - Energy. Erişim Adresi: www.ec.europa.eu/energy/efficiency/buildings/buildings_en.htm. Erişim Tarihi: 10.11.2020.

EİGM (2020). Enerji İşleri Genel Müdürlüğü Denge tabloları, Erişim Adresi: https://www.eigm.gov.tr/tr-TR/Denge-Tablolari/Denge-Tablolari, Erişim Tarihi: 10.06.2020.

Erişim Adresi: http://www.iruse.ie/iruse/projects/-finishedprojects-/itobo/ Erişim Tarihi: 02.12.2020.

Erişim Adresi: https://www.iklim.istanbul/iklim/ Erişim Tarihi: 10.08.2020.

EUROSTAT (2020a). Energy Production and Imports-a statistical overview. Erişim Adresi: https://ec.europa.eu/eurostat/statisticsexplained/index.php/Energy_production_and_imports Erişim Tarihi: 10.06.2020.

EUROSTAT b (2020b). Oil and Petroleum Products-a statistical overview. Erişim Adresi: https://ec.europa.eu/eurostat/statisticsexplained/index.php?title=Oil_and_petroleum_produ cts_-_a_statistical_overview\#Oil_imports_dependency Erişim Tarihi: 10.06.2020.

FEEDNETBACK (2007). Feedback design for wireless networked systems. Funded under 7th FWP (Seventh Framework Programme) ICT-2007.3.7. Network embedded and control systems. Erişim Adresi: https://www.unipd.it/en/feednetback. Erişim Tarihi: 02.12.2020.

GAWIND (2006). Grid-enabled automatic wireless network design, Funded under MOBILITY1.3.1. Marie Curie Host Fellowships - Transfer of knowledge (TOK) - Development Scheme. Erişim Adresi: https://cordis.europa.eu/project/id/42783 Erişim Tarihi: 02.12.2020.

Gökçe H. U. \& Gökçe K. U. (2013) Integrated system platform for energy efficient building operations. Journal of Computing in Civil Engineering. 10.1061/(ASCE)CP.19435487.0000288 (5 Jan 2013) SCI A.

Gökçe H.U. \& Gökçe K. U. (2017). "Intelligent Building Energy Management System for Energy Optimised Office Spaces" 16. International Conference of Sustainable Energy Technologies SET 2017. Bologna, Italy. Oxford University Press. ISBN (Print): 979-12-200-2203-3. 
Gökçe, C. \& Erol, M. (2020). Türkiye'de Tasarruf Açığı ve Enerji Açığının Ekonomik Büyüme ile İlişkisi: Nedensellik Analizi. Dumlupinar Üniversitesi Sosyal Bilimler Dergisi. 64, 102122;2020. E-ISSN: 2587 005X http://dergipark.gov.tr/dpusbe

Gökçe, H. U \& Gökçe K. U. (2011). Multi Dimensional Information Management Platform for Wireless Embedded Monitoring of Building Performance Data. Proceedings of the $11^{\text {th }}$ International Conference on Construction Applications of Virtual Reality, Weimar, Germany. ISBN: 978-3-86068-458-0.

IEA (2020). International Energy Agency Erişim Adresi: https://www.iea.org/countries/turkey Erişim Tarihi: 10.06.2020.

Itard, L., Meijer, F., Vrins, E. \& Hoiting, H. (2008). Building renovation and modernisation in Europe: State of the art review. ERABUILD. Nederlands: TU Delft, 2008. Erişim Adresi: http://iibw.at/documents/2008\%20OTB\%20TU\%20Delft.\%20Erabuild\%20Building.\%20R enovation\%20Europe.pdf

ITOBO (2011). Information Technologies for Optimized Building Operations.

İIDEP (2020). 2016 - 2020 İstanbul İklim Değişikliği Eylem Planı.

Jagemar, L., Olsson, D. \& Schmidt, F. (2007). The EPBD and Continuous Commissioning. Project $\begin{array}{lllll}\text { Report. } & \text { Building } & \text { EQ. } & \text { EIE/06/038/SI2 }\end{array}$ https://ec.europa.eu/energy/intelligent/projects/sites/ieeprojects/files/projects/documents/bu ilding_eq_the_epbd_and_continuous_commissioning_en.pdf

Keller, M., O'Donnell, J., Keane, M. \& Gökçe, H. U. (2008). Integrating the specification, acquisition and processing of building performance information. Journal of Tsinghua Science and Technology, vol. 13, no. 1, pp. 1-6. ISSN 1007-0214 01/17. http://citeseerx.ist.psu.edu/viewdoc/download?doi=10.1.1.457.374\&rep=rep1\&type=pdf

Le Donne, Alessia \& Scaccabarozzi, Andrea \& Tombolato, Sara \& Acciarri, Maurizio \& Abbotto, Alessandro \& Binetti, S.. (2013). Solar Photovoltaics: A Review. Reviews in Advanced Sciences and Engineering. 2. 170-178. 10.1166/rase.2013.1030.

Loney K. (2004). Oracle Database 10g The Complete Reference, California: Oracle Press McGrawHil/Osborne. ISBN-13: 978-0072253511 2004.

OME (Observatoire Méditerranéen de l'Energie). (2014). Mediterranean Energy Perspectives TURKEY. Erişim Adresi: http://www.tenva.org/wp-content/uploads/2014/09/MEP-Turkey-Executive-SummaryEnglish.pdf

Price, L. (2006). Sectoral Trends in Global Energy Use and Greenhouse Gas Emissions. Lawrence Berkeley National Laboratory. USA. https://www.osti.gov/servlets/purl/888753

UNFCCC (2018). United Nations Climate Change Annual Report 2017. ISBN: 978-92-9219-175-

7. https://unfccc.int/resource/annualreport/media/UN-Climate-AR17.pdf

\section{Beyan ve Açıklamalar (Disclosure Statements)}

1. Araştırmacıların katkı oranı beyanı / Contribution rate statement of researchers:

1. Yazar/First author 50\% 2. Yazar/Second author $50 \%$

2. Yazarlar tarafından herhangi bir çıkar çatışması beyan edilmemiştir (No potential conflict of interest was reported by the authors). 